Article

\title{
Evaluation of the Terrestrial Ecosystem Model Biome-BGCMuSo for Modelling Soil Organic Carbon under Different Land Uses
}

\author{
Maša Zorana Ostrogović Sever ${ }^{1, *}$, Zoltán Barcza ${ }^{2,3,4}{ }^{\mathbb{D}}$, Dóra Hidy ${ }^{3}$, Anikó Kern ${ }^{5} \mathbb{D}$, Doroteja Dimoski ${ }^{1}$, \\ Slobodan Miko ${ }^{6}{ }^{\mathbb{D}}$, Ozren Hasan ${ }^{6}{ }^{(D)}$, Branka Grahovac ${ }^{7}$ and Hrvoje Marjanović ${ }^{1}(\mathbb{D})$
}

Citation: Ostrogović Sever, M.Z.; Barcza, Z.; Hidy, D.; Kern, A.; Dimoski, D.; Miko, S.; Hasan, O.; Grahovac, B.; Marjanović, H. Evaluation of the Terrestrial Ecosystem Model Biome-BGCMuSo for Modelling Soil Organic Carbon under Different Land Uses. Land 2021, 10, 968. https://doi.org/10.3390/ land 10090968

Academic Editors: Cezary Kabala and Manuel López-Vicente

Received: 28 July 2021

Accepted: 10 September 2021

Published: 14 September 2021

Publisher's Note: MDPI stays neutral with regard to jurisdictional claims in published maps and institutional affiliations.

Copyright: (c) 2021 by the authors. Licensee MDPI, Basel, Switzerland. This article is an open access article distributed under the terms and conditions of the Creative Commons Attribution (CC BY) license (https:// creativecommons.org/licenses/by/ $4.0 /)$
1 Croatian Forest Research Institute, Cvjetno naselje 41, HR-10450 Jastrebarsko, Croatia; doroteja@sumins.hr (D.D.); hrvojem@sumins.hr (H.M.)

2 Department of Meteorology, Eötvös Loránd University, Pázmány P. st. 1/A, H-1117 Budapest, Hungary; zoltan.barcza@ttk.elte.hu

3 Excellence Center, Faculty of Science, Eötvös Loránd University, Brunszvik u. 2, H-2462 Martonvásár, Hungary; hidyd@elte.hu

4 Faculty of Forestry and Wood Sciences, Czech University of Life Sciences Prague, Kamýcká 129, 16521 Prague, Czech Republic

5 Department of Geophysics and Space Sciences, Eötvös Loránd University, Pázmány P. st. 1/A, H-1117 Budapest, Hungary; anikoc@nimbus.elte.hu

6 Croatian Geological Survey, Sachsova 2, HR-10000 Zagreb, Croatia; smiko@hgi-cgs.hr (S.M.); ohasan@hgi-cgs.hr (O.H.)

7 Ministry of Agriculture, Directorate for Professional Support to the Development of Agriculture and Fisheries, J. J. Strossmayera 3, HR-31500 Našice, Croatia; branka.grahovac@mps.hr

* Correspondence: masao@sumins.hr

Abstract: Soil organic carbon (SOC) is a mandatory pool in national inventory reports on greenhouse gas (GHG) emissions and removals to the UNFCCC. Hence, its accurate assessment is important. Modelling SOC changes for national GHG reports is encouraged, but the uncertainty related to this pool still presents a significant challenge; thus, verifying modelling results with field observations is essential. We used the process-based model Biome-BGCMuSo and assessed its suitability for use in Croatia's GHG reporting. We modelled SOC stocks in the top $30 \mathrm{~cm}$ of the mineral soil layer (SOC 30$)$ for four different land-use (LU) categories (Deciduous/Coniferous Forest, Grassland and Annual Cropland) distributed in three biogeographical regions (Alpine, Continental and Mediterranean) and compared them with results of a national soil survey. A total of 573 plot level simulations were undertaken and results were evaluated at three stratification levels (LU, LU $\times$ biogeographical region, and plot). The model reproduced the overall country mean of $\mathrm{SOC}_{30}$ with no overall bias, and showed good performance at the LU level with no significant $(p<0.05)$ difference for all LUs except Deciduous Forest (11\% overestimation). At finer stratifications, the model performance considerably worsened. Further model calibration, improvement and testing, as well as repeated soil survey are needed in order to assess the changes in $\mathrm{SOC}_{30}$ and to evaluate the potential of the Biome-BGCMuSo model for use in GHG reporting.

Keywords: biogeochemical modelling; spatial modelling; soil national inventory; national inventory report; forests; croplands; grasslands

\section{Introduction}

Soil organic carbon (SOC) is one of five mandatory pools in national reports on greenhouse gas (GHG) emissions and removals that must be submitted pursuant to the United Nations Framework Convention on Climate Change (UNFCCC) and accounted for under the Kyoto Protocol (KP) [1] and Paris Agreement (PA) [2]. Carbon (C) emissions and removals within the SOC pool are included in the land use, land-use change and forestry (LULUCF) sector of the National Inventory Reports (NIR) of the Parties to the UNFCCC. 
LULUCF is the only sector that accounts for $\mathrm{C}$ removal; therefore, in some regions, it has been identified as essential in reaching the goal of climate neutrality (The European Green Deal) [3]. Considering that SOC is the largest terrestrial C pool $[4,5]$ and that warmer climate can stimulate SOC losses [6,7], with the possibility of forming a positive feedback loop between the carbon cycle and climate warming [8], it is important to make an accurate assessment of SOC stocks and changes.

The uncertainties in the LULUCF sector estimates are currently being emphasised [9]. According to principles required by International Panel on Climate Change, national reports need to be transparent, complete, consistent, comparable and accurate [10]. This means that each party needs to deliver a fully documented report in which accurate estimates are given for all relevant categories (i.e., land uses and pools) of GHG sources and sinks, throughout the time series. Of all the mandatory pools, namely aboveground and belowground live biomass, deadwood, litter and soil organic matter, reporting on net $C$ change in soil under different land uses (LU) over time is often most challenging.

The simplest approach of assessment (Tier 1) in mineral SOC stocks assumes no change, whereas the use of higher tiers requires integration of field measurements and modelling. Soil C modelling is cost effective and is already in use for national reporting where soil models such as RothC [11,12], Yasso07 [13-16] or CENTURY [17] have been used. Nevertheless, field measurements of soil C stocks, although expensive and time consuming, are necessary for model calibration and validation [18-20]. In order to address uncertainty in reporting related to the SOC pool, there is an increased interest in verifying the results of process-based models with the results from field observations [20].

There is an extensive literature on SOC modelling [21-23]. Most often, SOC is modelled with soil C models (e.g., Yasso), in which processes in predefined soil pools are modelled, whereas organic $C$ inputs to the soil pool are user-defined or estimated through various allometric functions [24]. SOC can also be modelled with ecosystem models that simulate processes throughout the entire soil-plant-atmosphere continuum, making all ecosystem pools (aboveground and belowground) sensitive to changes in climate or land management.

Due to the great variability in SOC under different LU types, LU change is a strong driver of SOC change $[25,26]$. Furthermore, management activities are found to have a strong effect on SOC [27], and there is also evidence that sustainable management practices can contribute to maintaining soil $\mathrm{C}$ sinks and stocks [28,29]. Studies suggest that projected changes in climate, e.g., increasing temperature and prolonged droughts, may promote soil respiration and facilitate a decrease in SOC [30-32]. With respect to the ongoing changes in environmental conditions, ecosystem models which consider both the vegetation and the soil are useful for predicting future SOC stocks.

Biome-BGCMuSo is a terrestrial ecosystem model that simulates the storage and flux of water, carbon and nitrogen in the soil-plant-atmosphere system. It is a new variant of the well-known Biome-BGC model [33], with a variety of new adjustments and features [34]. The main improvement is a multilayer soil sub-model (therefore its name $\mathrm{MuSo}-\mathrm{Multilayer}$ Soil) that allows a more accurate representation of soil profiles regarding soil texture and bulk density, which can contribute to the improvement of simulation of $C$ and water fluxes. Another important feature is the implementation of several management options that make the model suitable for modelling ecosystems under different management practices. Considering a long history of the Biome-BGC model [33], with numerous improvements [35-38], calibrations and validations [39-42], and global use [36,42-44], the recent improvements in Biome-BGCMuSo [34] provide a valuable tool for simulating SOC stocks and changes under various $\mathrm{LU}$, management and climate scenarios.

The main challenges in using process-based models are the collection of input data (meteorological, ecophysiological and site variables) at the adequate temporal and spatial resolution, and the complex task of model calibration and validation, which has high computing requirements [45]. Therefore, such models are often calibrated and validated using well-equipped research sites (e.g., eddy-covariance or long-term monitoring sites) 
which are representative of specific biomes [46,47], and subsequently used for simulations and/or predictions at various temporal and spatial scales $[18,43,48]$. To account for spatial variability within a specific ecosystem, multi-site calibration and validation are recommended $[49,50]$. As a relatively small country in Europe, but with very high biogeographical diversity, Croatia is an ideal area for testing the model performance for specific ecosystems in different biogeographical regions.

Although $C$ stock changes are more important than current $C$ stocks for GHG accounting, in order to obtain reliable estimates of $C$ stock changes it is important to first be able to properly estimate current $C$ stocks. Therefore, the aim of this research was to test the suitability of the Biome-BGCMuSo terrestrial ecosystem model for modelling SOC stocks in the top $30 \mathrm{~cm}$ of the soil mineral layer, at the national scale, under different land uses, through comparison with field data from a national soil survey.

\section{Materials and Methods}

\subsection{Study Area}

The research focused on the total area of Croatia, which is distributed among three biogeographical regions: Continental, Alpine and Mediterranean (Figure 1) [51]. The Continental region covers the northern and central parts of Croatia, and is bounded to the south by the Dinarides mountains. It is mainly an area of lowlands and low hills at 200-500 m a.s.l., with Pannonian Mountains reaching 1059 m (Mt Ivanščica) in the north. It is characterised by a temperate rainy climate with warm summers and cold winters, and two precipitation maxima classified as Cfwbx" according to the Köppen classification [52]. The mean annual temperature (Tair) is around $10^{\circ} \mathrm{C}$ and annual precipitation (P) ranges from approximately 600 to $1200 \mathrm{~mm}$ following an east-west gradient [53]. The soil parent material is mainly alluvial deposits (lowlands) and silicate rocks (hills and mountains) [54,55]. The geological background consists of magmatic, clastic and metamorphic rocks $[56,57]$. The Alpine region of Croatia is situated between the Continental and Mediterranean regions, and covers the central belt of the Dinarides (i.e., high Dinaric Alps) at elevations mainly above $500 \mathrm{~m}$ and with the highest mountain peak at $1831 \mathrm{~m}$ a.s.l (Mt Dinara). The climate of the Alpine region is characterised by relatively short and cool summers and long winters with abundant snowfall (Cfsbx") [52]. According to the Zalesina meteorological station, situated at $750 \mathrm{~m}$ a.s.l., Tair is $6.6^{\circ} \mathrm{C}$ and $\mathrm{P}$ is $2021 \mathrm{~mm}$, whereas above $1200 \mathrm{~m}$ a.s.l. a harsher climate prevails (Dfsbx" according to the Köppen classification) [52] with Tair of $3.6^{\circ} \mathrm{C}$ and P of $1892 \mathrm{~mm}$ (Zavižan meteorological station at $1594 \mathrm{~m}$ a.s.l., for the period 1961-1990) [53]. The soil parent material is mainly limestone and dolomite [54,55], developed on the geological background consisting dominantly of carbonate Mesozoic rocks [56,57]. The Mediterranean region in Croatia covers coastal areas and islands in the Adriatic Sea. It is diverse in orography, with an elevation range of 0-1000 $\mathrm{m}$ a.s.l. The climate is warm with hot summers and mild winters, and classified as Csa according to Köppen [52], with Tair of 13.1 and $15.5^{\circ} \mathrm{C}$, and $\mathrm{P}$ of 1177 and 936 $\mathrm{mm}$, respectively. The soil parent material is mainly carbonate. Both the Alpine and Mediterranean regions of Croatia feature karst landforms (e.g., sinkholes and caves) and disappearing streams.

The main LU categories in Croatia are Forest land (40.9\%), followed by Cropland $(26.3 \%)$ and Grassland (19.4\%) (Table 1). The majority of forests are deciduous and the main tree species are common beech $(37.2 \%)$, pedunculate oak $(11.6 \%)$, sessile oak $(9.4 \%)$, and common hornbeam (8.4\%) [58]. Crops are predominantly annual (maize, wheat and potato). 
Table 1. Area of land-use categories in Republic of Croatia in 2016 according to HR NIR 2020 [59].

\begin{tabular}{cccc}
\hline \multirow{2}{*}{ LU Category } & $\begin{array}{c}\text { National Inventory } \\
\text { Report Categories }\end{array}$ & Area in 2016 (kha) & Share (\%) \\
& Deciduous forests & 1618.3 & $28.6 \%$ \\
Forest land & Coniferous forests & 209.4 & $3.7 \%$ \\
& Forests out of yield & 484.7 & $8.6 \%$ \\
Cropland & Annual cropland & 1386.0 & $24.5 \%$ \\
Grassland & Perennial cropland & 105.1 & $1.9 \%$ \\
Wetlands & Grassland & 1096.6 & $19.4 \%$ \\
Settlements & Wetlands & 74.1 & $1.3 \%$ \\
Other land & Settlements & 203.6 & $3.6 \%$ \\
Land-use change & Other land & 238.2 & $4.2 \%$ \\
\hline \multicolumn{2}{c}{ Land-use change } & 243.3 & $4.3 \%$ \\
\hline
\end{tabular}

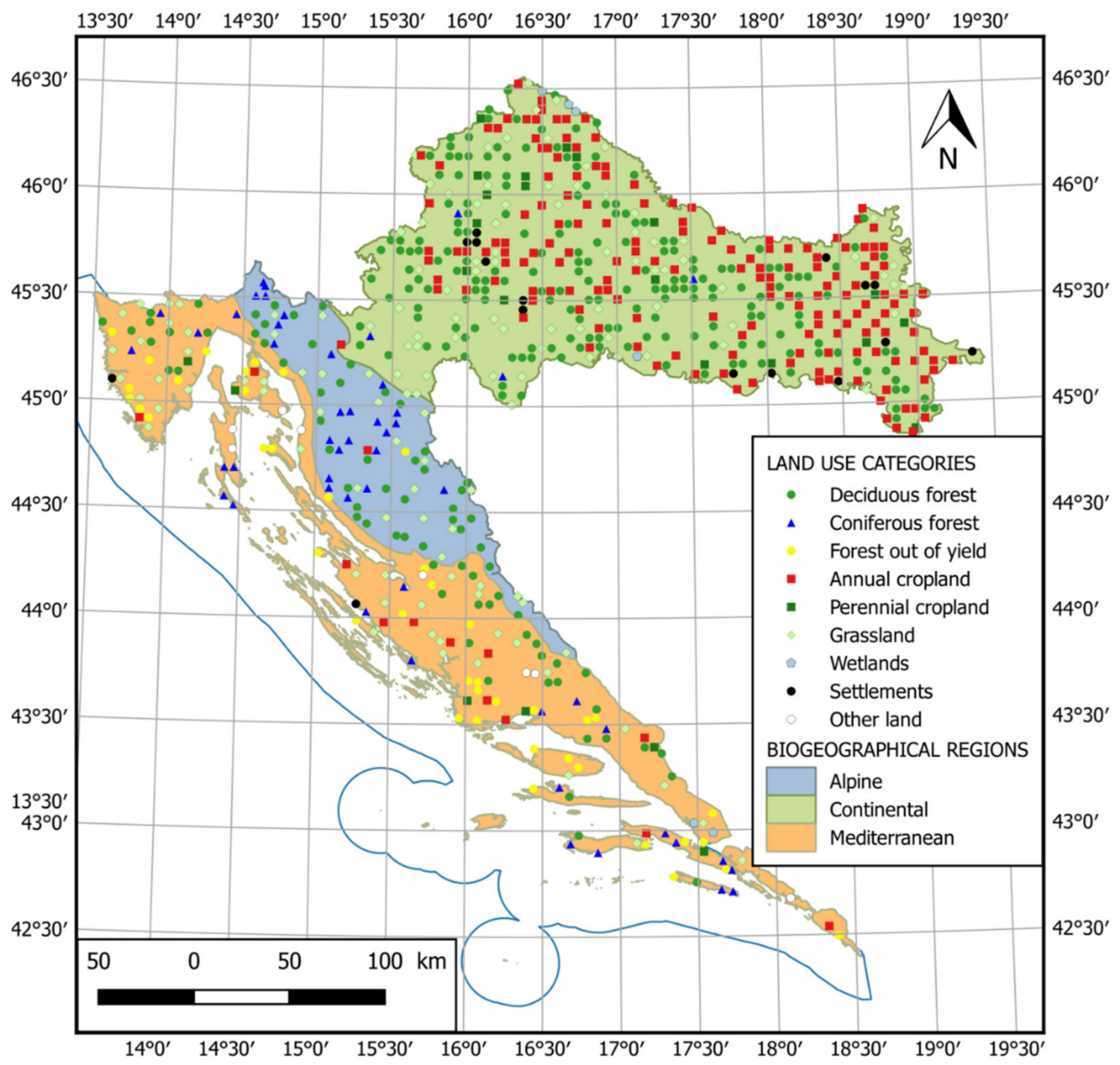

Figure 1. Biogeographical regions according to the European Environmental Agency [51] and national soil survey field plots distributed between land-use categories in Croatia in 2016 according to HR NIR 2020 [59]. 


\subsection{Field Measurements and Laboratory Analysis}

Soil survey in Croatia was conducted in line with the IPCC guidelines [10], during 2015 and 2016, at 725 plots distributed among different LU categories (Figure 1). At each plot within the Forest land category, $5 \mathrm{~m}$ from the plot centre, mineral soil was sampled at 6-8 positions in the directions N, NE, E, SE, S, SW, W and NW. Soil cores were taken with a split tube sampler (Eijkelkamp) to the total depth of $30 \mathrm{~cm}$ and divided into $10 \mathrm{~cm}$ deep layers. In the case where the use of a sampler was not possible due to the high content of rocks at the site, soil samples were collected from one soil pit sampled in three layers $(0-10,10-20$ and 20-30 cm). In cases when the soil was less than $30 \mathrm{~cm}$ deep, the soil depth was recorded. At plots within LU categories other than FL, the soil was sampled similarly, but only at 4 positions per plot due to lower heterogeneity in comparison with the forest soils. An additional difference was the sampling within the Annual Cropland LU category, where soil samples were collected from two layers $(0-20$ and 20-30 cm). Soil sampling in two separate layers $(0-10$ and $10-20 \mathrm{~cm})$ at plots within AC LU was not justifiable due to soil tilling and mixing of the topsoil layer.

At all non-rocky sites, soil bulk density was estimated by taking three soil samples per layer using Kopecky cylinders. At rocky sites, soil bulk density was estimated from the soil pit using inert quartz sand for estimating the volume of the soil pit according to the ISO standard (ISO 11272:1998). Soil samples were sieved, oven-dried and weighed. For every plot, soil samples from a given layer were then pooled together, homogenised and analysed for soil texture and carbon content. Soil organic carbon (SOC) of soil samples was determined using a Thermo Scientific FLASH 2000 Soil Nitrogen and Carbon analyser. This method allows direct measurements of the total carbon (TC). Carbonates were removed by treating soil samples with $4 \mathrm{M} \mathrm{HCl}$, and heating in a centrifuge tube sitting in a hot block for $2 \mathrm{~h}$. The insoluble residue was washed with Milli-Q water and centrifuged $(2 \times)$, freeze dried and weighed. The carbon content of the insoluble residue after $\mathrm{HCl}$ treatment is the soil organic carbon (SOC).

\subsection{The Biome-BGCMuSo Model_Parameterisation and Input Data Collection}

In this research we used a model Biome-BGCMuSo 4.0., a biogeochemical model that simulates the storage and flux of water, carbon and nitrogen in the soil-plant-atmosphere system [34]. Although newer model versions are also available, version 4.0 has been extensively evaluated [34]. The main improvement of the Biome-BGCMuSo in comparison to the original Biome-BGC model is a multilayer soil sub-model that has 7 layers (i.e., 0-10, 10-30, 30-60, 60-100, 100-200, 200-300 and 300-1000 cm). The Biome-BGCMuSo simulates soil temperature, soil water content, root mass proportion, soil organic $C$ and mineral $\mathrm{N}$, soil moisture stress index with accompanying senescence, and maintenance root respiration flux in each of the layers. The decomposition process is represented as a converging cascade scheme in which organic material, initially passed from plant pools to litter and coarse woody debris pools, decomposes and passes through a cascade of different pools with specific turnover times [60]. It should be noted that the decomposition scheme of Biome-BGCMuSo corresponds to the decomposition scheme, together with specific decomposition constants, used in the CLM-CN model [60]. In each step, organic material is partially respired following the decay rates described by the first-order kinetics [11,23,61]. Another major feature of Biome-BGCMuSo v.4.0 is the implementation of several management options, i.e., harvest, ploughing, fertilisation, planting, thinning and irrigation. The model is freely available online with the source code and full documentation at http:// nimbus.elte.hu/bbgc/index.html (accessed on 23 July 2021).

Three main datasets are needed as model inputs: daily meteorological data, sitespecific data and ecophysiological parameters. Optionally, the user can provide yearly atmospheric $\mathrm{CO}_{2}$ concentration, yearly atmospheric $\mathrm{N}$ deposition and management data. Meteorological data needed as model drivers are daily maximum and minimum air temperature, daily precipitation amount, daylight mean global radiation, vapour pressure deficit and geographical coordinates used by the model for the calculation of the daylength. 
Spatially explicit data that fully match these requirements are available for Central Europe within the FORESEE database [62]. FORESEE v3.1 is an open-access gridded meteorological database with a spatial resolution of $1 / 6^{\circ} \times 1 / 6^{\circ}$, spanning between $10^{\circ} 55^{\prime}-28^{\circ} 05^{\prime} \mathrm{E}$ and $42^{\circ} 35^{\prime}-51^{\circ} 05^{\prime} \mathrm{N}$, and covering the $1951-2100$ period with observations and climate model-based projections.

Site-specific data include soil texture, maximum rooting depth, long-term mean air temperature and air temperature range, elevation, latitude and shortwave albedo. These data were estimated from field observations (soil texture, and maximum rooting depth), from the processing of FORESEE database (air temperature) and its ancillary data (elevation and latitude) and based on expert judgment (albedo). Lists of ecophysiological constants or parameters (EPC list) are biome specific or species specific. Lists of ecophysiological parameters used in this research are provided in Table A1. We used EPC lists for Grassland, Cropland and Deciduous forest published in Hidy et al. (2016) [34], and adjusted a number of parameters according to Dalrymple and Dwyer (1967) [63], Barbosa et al. (2016) [64], Cleveland et al. (1999) [65] and Butler et al. (2001) [66] (Table A1). For consistency with LULUCF categories used in the National Inventory Report [59] we made a distinction between deciduous forests and coniferous forests based on White et al. (2000) [39], BondLamberty et al. (2005) [36] and Thornton et al. (2005) [67] (Table A1). For some LU (Forests out of yield, Perennial cropland, Wetlands, Settlement, Other Land; Table 1) it was not possible to obtain lists of ecophysiological parameters due to the large heterogeneity of those LU categories.

Of the optional input data, we used yearly atmospheric $\mathrm{CO}_{2}$ concentration data from Mauna Loa Observatory [68] and ice cores [69], and yearly atmospheric N deposition data were estimated from the literature [70]. LU category-specific data on average management practices were estimated based on national regulations (Forest land), statistical yearbooks, through consultations with local experts and authors' experience (Cropland and Grassland) (Table A2).

\subsection{Soil Organic Carbon (SOC) Modelling}

We performed spatial modelling of SOC down to $30 \mathrm{~cm}\left(\mathrm{SOC}_{30}\right)$ for four different $\mathrm{LU}$ categories, i.e., Deciduous forests (DF), Coniferous forests (CF), Annual cropland (AC) and Grassland (GL). By modelling within the selected four LU categories, we accounted for 4310.4 kha or $76.2 \%$ of Croatia's land territory (Table 1 ).

The model simulation had three phases: spin-up, transient and normal run. Spin-up (self-initialisation or equilibrium run) is a widely used method for the estimation of the initial conditions of biogeochemical models [71]. Using this method, long-term simulations are initiated starting from zero SOC and reusing the meteorological data that drives the simulations. The aim of the spin-up simulation is to reach equilibrium with the current climate using predefined $\mathrm{N}$ deposition and atmospheric $\mathrm{CO}_{2}$ concentration values. It was simulated for 6000 years, using: repeating meteorology from 1951-1999, fixed atmospheric $\mathrm{CO}_{2}$ concentration of $290 \mathrm{ppm}$, fixed atmospheric $\mathrm{N}$ deposition of $0.0002 \mathrm{~kg} \mathrm{~N} \mathrm{~m}^{-2} \mathrm{yr}^{-1}$ and annual fire-mortality rate of 0.002 (personal assessment). The transient run was simulated for 100 years from 1900 to 1999 , using the same meteorology as in spin-up, estimates (1900-1957) [69] and records (1958-1999) [68] of atmospheric $\mathrm{CO}_{2}$ concentration, estimates of the atmospheric $\mathrm{N}$ deposition [70], and LU-specific management activities (Table A2). The purpose of the transient run is to alleviate undesired ecosystem behaviour caused by a sharp change in atmospheric $\mathrm{CO}_{2}$ concentration and atmospheric $\mathrm{N}$ deposition between the spin-up and normal simulation. The normal run was performed for the period 1990-2016 using meteorology data from the FORESEE database [62], atmospheric $\mathrm{CO}_{2}$ concentration from Mauna Loa [68], atmospheric $\mathrm{N}$ deposition [70] and LU-specific management activities (Table A2).

Meteorological data, site-specific data and ecophysiological parameters were all spatially explicit and their intersection at each sample plot resulted in a table that contained all the specific attributes needed for the model run. Of 725 sample plots within the soil 
survey, 629 plots were under four LU categories of interest, for which we performed model simulation. One plot was excluded from further analysis as a probable outlier due to the unrealistically high measured value of $\mathrm{SOC}_{30}\left(>350 \mathrm{tC} \mathrm{ha}{ }^{-1}\right)$. Of 628 field plots for which we performed a model run, 55 model runs resulted in unsuccessful simulations (zero live biomass at some point during the simulation). A possible reason for this may be the model sensitivity to $\mathrm{N}$ that may result in an unsuccessful growth (and death) of vegetation during the spin-up phase due to high $\mathrm{N}$ demand of vegetation and low $\mathrm{N}$ availability at specific locations. For more details on the technical components of the model and simulation, see the User's Guide [72]. Finally, we achieved a total of 573 successful plot level simulations for use in the model-data comparison (dataset is available in the Supplementary Materials).

\subsection{Model Evaluation}

Biome-BGCMuSo was previously evaluated with flux and biometric data for C3 grassland, C4 maize and pedunculate oak forest [34], in addition to tree-rings data for oak forests [73]. In this research, validation of the model was performed through comparison of modelled and measured $\mathrm{SOC}_{30}$ data at three different levels: land use (regardless of the biogeographical region), land use $\times$ biogeographical region and plot.

For each LU category, and for the LU $\times$ biogeographical region level, the difference between the modelled and the measured $\mathrm{SOC}_{30}$ stocks was assessed with a Student's $t$-test. The differences in $\mathrm{SOC}_{30}$ stocks between LU categories were tested with the KruskalWallis $\mathrm{H}$ test, separately for the modelled and the measured $\mathrm{SOC}_{30}$ stocks. Furthermore, evaluation of model results was performed using quantitative measures, namely coefficient of determination $\left(\mathrm{R}^{2}\right)$ of the linear regression, mean absolute error (MAE), root mean square error (RMSE) and Nash-Sutcliffe model efficiency (NSE). Finally, analysis of residuals, estimated as the difference between measured and modelled $\mathrm{SOC}_{30}$ data, was performed at the plot level.

Uncertainty analysis at the plot level was not included because it exceeds the scope of this study.

\section{Results}

To test the suitability of the model for reporting within the National GHG Inventory, we aggregated our model results according to different LU categories and found a strong correlation between measured and modelled $\mathrm{SOC}_{30}$ stocks (Figure 2).

We observed that modelled and measured $\mathrm{SOC}_{30}$ stocks significantly differ $(p<0.01)$ for DF only, with the model overestimating the soil carbon stocks (Figure 2). The magnitude of overestimation (mean difference) was $7.38 \mathrm{tC} \mathrm{ha}^{-1}(11.0 \%)$. For all other LU categories, there was no statistically significant $(p<0.05)$ difference between the measured and the modelled $\mathrm{SOC}_{30}$ stocks.

Furthermore, the $\mathrm{SOC}_{30}$ stocks in the AC significantly $(p<0.01)$ differ from $\mathrm{SOC}_{30}$ stocks in all other LU categories for both the modelled results and the measured data. Measured $\mathrm{SOC}_{30}$ in DF is significantly $(p<0.05)$ lower than the measured $\mathrm{SOC}_{30}$ in GL, whereas modelled $\mathrm{SOC}_{30}$ in GL significantly $(p<0.01)$ differs from both DF and CF categories.

For every LU category, the measured $\mathrm{SOC}_{30}$ showed greater variation in comparison to the modelled one, with the measured $\mathrm{SOC}_{30}$ in $\mathrm{CF}$ having the highest and the modelled $\mathrm{SOC}_{30}$ in $\mathrm{AC}$ having the lowest coefficient of variation (CV) (Table 2). Moreover, measured variability within different LU was similar (CV of 39\% to $45 \%$ ), whereas the variability in the modelled $\mathrm{SOC}_{30}$ stock was larger for DF and CF LU categories (CV of $28 \%$ and $29 \%$, respectively) than for GL (22\%) and AC (19\%). 


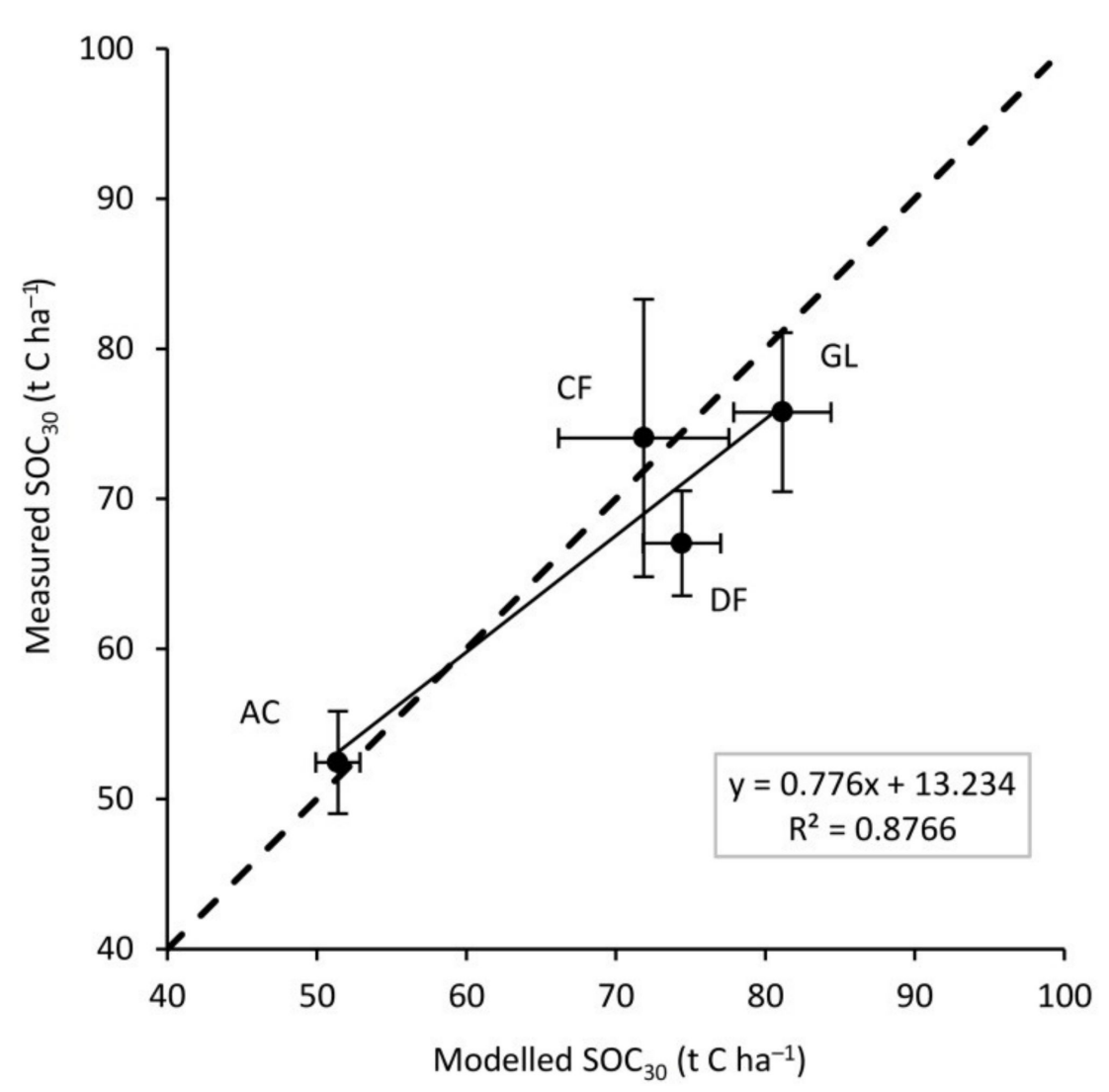

Figure 2. Comparison of measured and modelled mineral soil organic carbon stocks down to $30 \mathrm{~cm}$ at the level of land-use category. Average $\pm 1.96 \mathrm{SE}$. The dashed line is a 1:1 line.

Table 2. Variability in measured and modelled soil organic carbon down to $30 \mathrm{~cm}$ regarding different land-use categories (average \pm standard error).

\begin{tabular}{|c|c|c|c|c|c|}
\hline \multirow{2}{*}{ LU Category } & \multirow{2}{*}{$\mathbf{N}$} & \multicolumn{2}{|c|}{ Measured $\mathrm{SOC}_{30}$} & \multicolumn{2}{|c|}{ Modelled $\mathrm{SOC}_{30}$} \\
\hline & & tC ha-1 & CV $(\%)$ & t C ha-1 & CV (\%) \\
\hline $\begin{array}{l}\text { Deciduous } \\
\text { forests (DF) }\end{array}$ & 241 & $67.04 \pm 1.78$ & 41 & $74.42 \pm 1.32$ & 28 \\
\hline $\begin{array}{l}\text { Coniferous } \\
\text { forests }(C F)\end{array}$ & 51 & $74.05 \pm 4.71$ & 45 & $71.86 \pm 2.90$ & 29 \\
\hline $\begin{array}{l}\text { Annual } \\
\text { croplands } \\
\text { (AC) }\end{array}$ & 161 & $52.44 \pm 1.74$ & 42 & $51.41 \pm 0.75$ & 19 \\
\hline $\begin{array}{l}\text { Grasslands } \\
\text { (GL) }\end{array}$ & 120 & $75.77 \pm 2.70$ & 39 & $81.14 \pm 1.66$ & 22 \\
\hline Total & 573 & $65.39 \pm 1.19$ & 44 & $69.13 \pm 0.88$ & 30 \\
\hline
\end{tabular}

In preparation of the country's NIR with mandatory land stratification according to the LU, the IPCC GPG considers additional land stratification, with respect to climate, soil types, etc., to be good practice [10]. Although the model showed good performance at the LU level, disaggregation of the results by the biogeographical regions revealed a significant mismatch between measured and modelled data (Figures 3 and A1). 


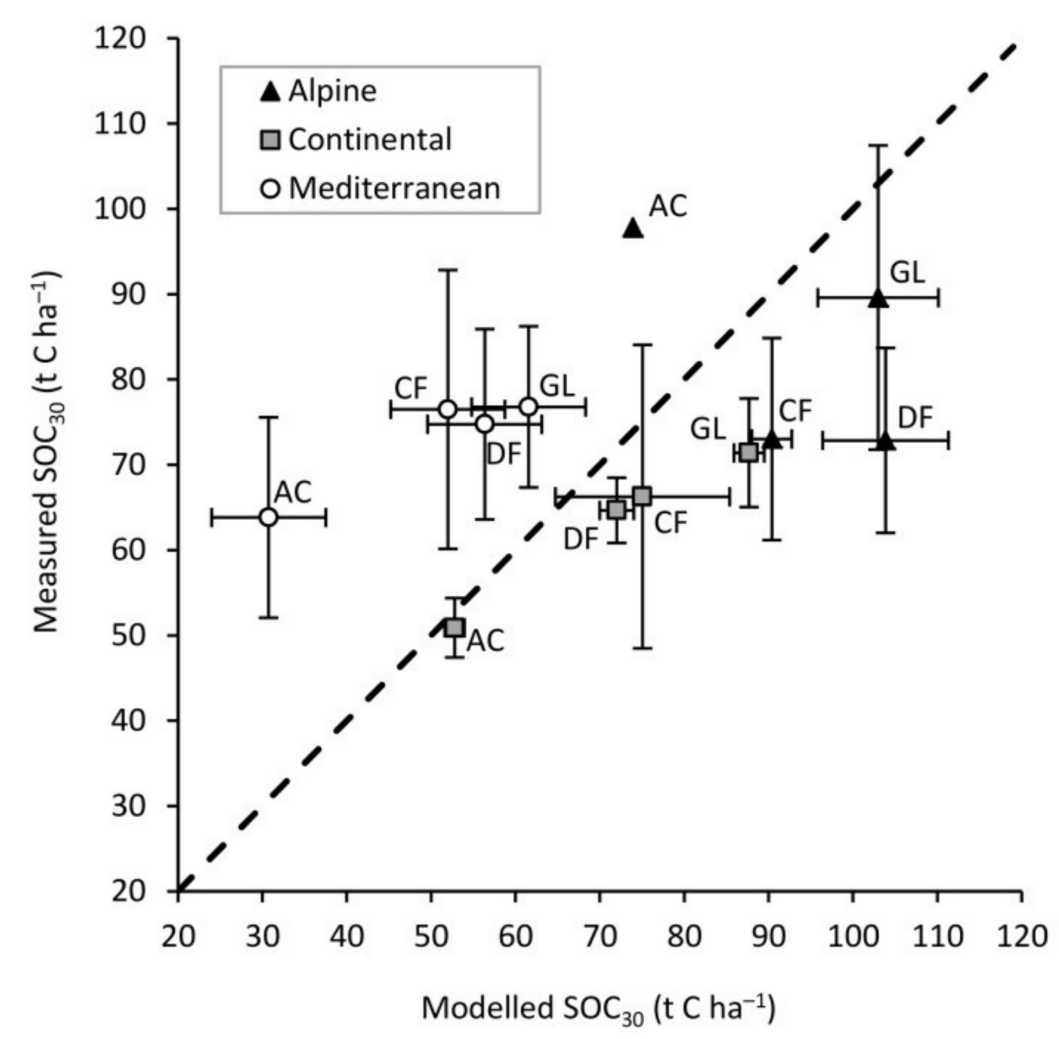

Figure 3. Comparison of measured and modelled soil organic carbon stocks down to $30 \mathrm{~cm}$ at the land use $\times$ biogeographical region level. Average \pm 1.96 SE. The dashed line is a 1:1 line.

For all LU categories within the Mediterranean region, a significant underestimation of the modelled $\mathrm{SOC}_{30}$ was observed. In contrast, an overestimation of the model was observed for DF and GL LU in the Continental region, and for the DF and CF LU categories in the Alpine region. For the AC in the Alpine region only, the modelled $\mathrm{SOC}_{30}$ was underestimated. However, because there were only two data points in this category, the confidence interval for this estimate is unknown and an estimate of model accuracy is unfeasible.

No statistically significant $(p<0.05)$ difference was observed between the measured and the modelled $\mathrm{SOC}_{30}$ stocks in Alpine GL, Continental CF and AC, and Mediterranean DF land-use categories.

The results also revealed an apparent gradient in modelled $\mathrm{SOC}_{30}$ with respect to biogeographical regions, namely Alpine $>$ Continental $>$ Mediterranean. No such gradient was observed in the measured data (Table 3, Figure A1). Furthermore, observed gradients in modelled data were present in all LU categories (Table 3, Figure A1).

Table 3. Variability in measured and modelled soil organic carbon down to $30 \mathrm{~cm}$ regarding different land-use categories and biogeographical regions (average \pm standard error).

\begin{tabular}{|c|c|c|c|c|c|c|}
\hline \multirow{2}{*}{$\begin{array}{c}\text { LU } \\
\text { Category } \\
\text { in NIR }\end{array}$} & \multirow{2}{*}{$\begin{array}{l}\text { Biogeographical } \\
\text { Region }\end{array}$} & \multirow{2}{*}{$\mathbf{N}$} & \multicolumn{2}{|c|}{ Measured $\mathrm{SOC}_{0-30 \mathrm{~cm}}$} & \multicolumn{2}{|c|}{ Modelled $\mathrm{SOC}_{0-30 \mathrm{~cm}}$} \\
\hline & & & $\mathbf{A V} \pm \mathbf{S E}$ & CV (\%) & $\mathrm{AV} \pm \mathrm{SE}$ & $\mathrm{CV}(\%)$ \\
\hline \multirow{3}{*}{$\begin{array}{l}\text { Deciduous } \\
\text { forest } \\
\text { (DF) }\end{array}$} & Alpine & 33 & $72.86 \pm 5.53$ & 44 & $103.86 \pm 3.81$ & 21 \\
\hline & Continental & 178 & $64.66 \pm 1.95$ & 40 & $72.00 \pm 1.03$ & 19 \\
\hline & Mediterranean & 30 & $74.75 \pm 5.69$ & 42 & $56.36 \pm 3.92$ & 38 \\
\hline \multirow{3}{*}{$\begin{array}{l}\text { Coniferous } \\
\text { forest } \\
\text { (CF) }\end{array}$} & Alpine & 24 & $73.02 \pm 6.04$ & 41 & $90.38 \pm 1.21$ & 7 \\
\hline & Continental & 4 & $66.26 \pm 9.07$ & 27 & $75.05 \pm 5.27$ & 14 \\
\hline & Mediterranean & 23 & $76.49 \pm 8.33$ & 52 & $51.99 \pm 2.43$ & 22 \\
\hline \multirow{3}{*}{$\begin{array}{l}\text { Annual } \\
\text { cropland } \\
\text { (AC) }\end{array}$} & Alpine & 2 & 97.79 & & 73.90 & \\
\hline & Continental & 147 & $50.89 \pm 1.77$ & 42 & $52.79 \pm 0.60$ & 14 \\
\hline & Mediterranean & 12 & $63.82 \pm 5.99$ & 33 & $30.74 \pm 1.71$ & 19 \\
\hline \multirow{3}{*}{$\begin{array}{l}\text { Grassland } \\
\text { (GL) }\end{array}$} & Alpine & 17 & $89.60 \pm 9.09$ & 42 & $102.97 \pm 3.65$ & 15 \\
\hline & Continental & 63 & $71.40 \pm 3.25$ & 36 & $87.69 \pm 0.92$ & 8 \\
\hline & Mediterranean & 40 & $76.78 \pm 4.82$ & 40 & $61.56 \pm 2.02$ & 21 \\
\hline
\end{tabular}


Further disaggregation of model results and comparison at the plot level revealed a very poor correlation between the measured and the modelled $\mathrm{SOC}_{30}$ stocks (Figure 4).
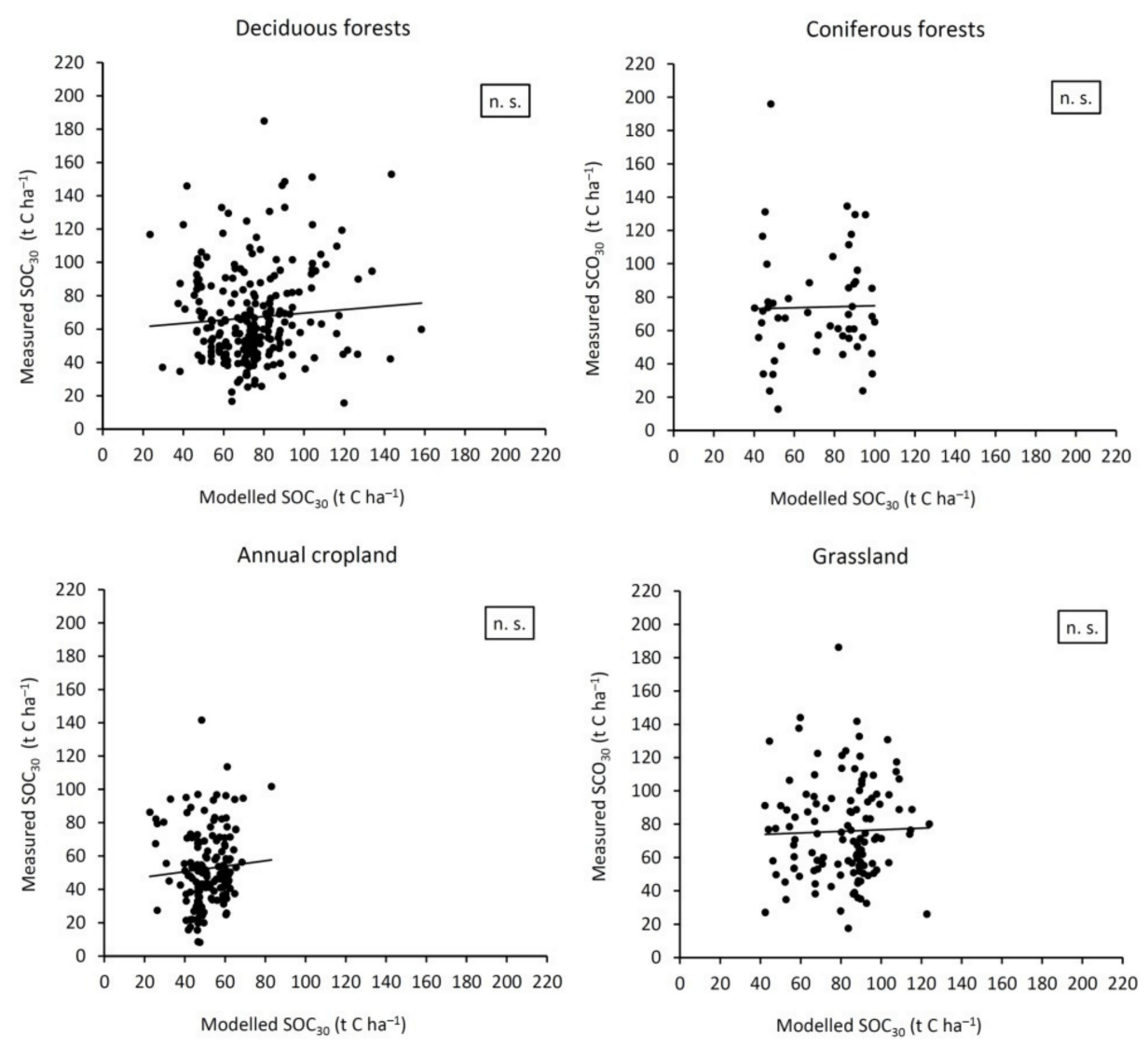

Figure 4. Comparison of measured and modelled soil organic carbon down to $30 \mathrm{~cm}$ at a plot level for different land-use categories.

Residual analysis (Figure A2) showed that the smaller values of the modelled $\mathrm{SOC}_{30}$ stocks are more likely underestimating the true values (positive residuals), whereas the large model values are likely overestimating the true values. The largest bias was observed for Deciduous forests $\left(R^{2}=0.308, p<0.001\right)$, and the lowest bias was observed for Annual cropland $\left(\mathrm{R}^{2}=0.116, p<0.001\right)$.

Summary results of the model evaluation at different levels of stratification are shown in Table 4. Although at the land-use level model performance is very good, when disaggregating results to lower scales, significant discrepancies between measured and modelled $\mathrm{SOC}_{30}$ data can be observed.

Table 4. Summary of model evaluation regarding different levels.

\begin{tabular}{cccccc}
\hline $\begin{array}{c}\text { Stratification } \\
\text { Level }\end{array}$ & $\mathbf{N}$ & $\mathbf{R}^{2}$ & MAE & RMSE & NSE \\
\hline $\begin{array}{c}\text { Land use } \\
\text { Land use } \times\end{array}$ & 4 & 0.877 & 3.993 & 4.721 & 0.736 \\
$\begin{array}{c}\text { Biogeograph- } \\
\text { ical } \\
\text { region } \\
\text { Plot }\end{array}$ & 11 & 0.240 & 17.021 & 19.319 & -3.086 \\
\hline
\end{tabular}

\section{Discussion}

During a long history of model development $[34,36,38,74]$ and due to a variety of calibration/validation studies $[40,75,76]$, Biome-BGC evolved and became increasingly more 
suitable for simulations across various terrestrial ecosystems $[77,78]$ and environmental gradients [42]. The results of our simulation with the new model variant (Biome-BGCMuSo) indicate its suitability for modelling the average mineral SOC down to $30 \mathrm{~cm}$, for Croatia at the national level, for four different land-use categories, namely Deciduous forests (DF), Coniferous forests (CF), Annual croplands (AC) and Grasslands (GL). For some of the more heterogeneous land-use categories, the model could not be initialised due to difficulties in defining adequate ecophysiological parameters. In particular, land-use categories Forests out of yield (i.e., maquis and shrubs), and Perennial croplands represent mixtures of several different types of ecosystems. For example, Forests out of yield include Mediterranean maquis and continental shrubs, whereas Perennial croplands include vineyards, olive groves and orchards. By comparison, the LU category Settlements encompasses a mosaic of sealed land, grass, parks, trees, water bodies, etc., making the selection of the appropriate EPC extremely difficult; in addition, the representativeness of the measured data is frequently questionable. The use of the unique list of ecophysiological parameters for modelling strata encompassing such diverse groups cannot be justified and would require a finer stratification of LU categories [79]. In addition, with a finer stratification (e.g., to vineyards, maquis, etc.) the number of plots for testing the modelling results would become prohibitively small. The lack of completeness at the national level represents a key issue if the model would be used for national GHG reporting, and would require the use of different tiers for different strata [10]. This may not be an issue, provided that in the country's NIR it has been demonstrated that only the modelled strata are Key categories [10]; that is, the contribution of the non-modelled strata to the overall GHG emissions and removals must be comparatively small, so that these can be safely estimated by some other, simpler, robust, albeit less precise, method.

At the LU category level, we observed a strong correlation between the mean modelled and the mean measured $\mathrm{SOC}_{30}$ stocks (Figure 2). However, this is due to $\mathrm{SOC}_{30}$ stocks in $\mathrm{AC}$, which are generally lower than those in grassland or forest land [79]. The variability in the measured $\mathrm{SOC}_{30}$ stocks for all LU is consistently larger than the variability in modelled $\mathrm{SOC}_{30}$ (Table 2). Considering the high spatial heterogeneity of soil in Croatia [54], high variability in measured $\mathrm{SOC}_{30}$ stocks is expected. On the other hand, the use of the "average" management practices in simulations, due to the lack of management data, contributes to lower variability in modelled $\mathrm{SOC}_{30}$ compared to the measured value, which reflects diverse management practices.

Disaggregation of the results to the level of land use within a specific biogeographical region, or to a plot level, shows worsening of the agreement between the modelled results and field measurements (Figures 3 and 4, and Figure A1). Variability in the measured $\mathrm{SOC}_{30}$ did not change significantly with stratification. The exceptions are $\mathrm{CF}$ and AC in the Mediterranean biogeographical region, which showed considerably larger (52\%) and smaller (33\%) variability than the overall means for CF and AC, respectively (compare Tables 2 and 3). This is most likely due to the high variability in the soil depth. $\mathrm{SOC}_{30}$ stocks, apart from the carbon content, strongly depend on the soil depth. In the Mediterranean part of Croatia, the karst landforms dominate and the variability in soil depth is very high, with many areas having less than $30 \mathrm{~cm}$ of soil [54]. Therefore, the greater variability in $\mathrm{SOC}_{30}$ is expected in forest LU categories, but not in croplands, because agriculture targets locations with more (i.e., deeper) soil [80].

High variability in the modelled $\mathrm{SOC}_{30}$ stocks in $\mathrm{CF}$ between biogeographical regions, with low variability within each, is most likely the result of the use of the single EPC list. Considering that for the Biome-BGCMuSo model there is only one published EPC list for the forest, namely, for pedunculate oak forests [34], to model $\mathrm{SOC}_{30}$ in $\mathrm{CF}$ we had to adjust some parameters (Table A1). Although we used a single EPC list for CF, we are aware that, for example, fir, spruce and pine differ significantly in their ecophysiology [81], which should be reflected in the EPC lists. Unfortunately, such species-specific EPC lists for Biome-BGCMuSo are currently lacking. Although we modelled each LU with a unique EPC list, we accounted for site-specific soil parameters, i.e., soil texture and maximum 
rooting depth, which are assumed to affect SOC processes [82,83]. Evidently, this is not sufficient and, for all LU categories, the modelled $\mathrm{SOC}_{30}$ stocks show gradients Alpine > Continental $>$ Mediterranean, which is not observed in the measured data.

Overestimation of the $\mathrm{SOC}_{30}$ stocks in the Alpine biogeographical region (for DF and $\mathrm{CF}$ ) and in the Continental region (for DF and GL), and underestimation in the Mediterranean region (all LU categories; Figure A1), is a strong indicator that a single EPC parameter list per LU used for all biogeographical regions is not adequate. Finer calibration, or at least adjustment of some of the model parameters, is needed at the level of LU within each biogeographic region. For example, parameters $\mathrm{C} / \mathrm{N}$ of different plant organs and/or $\mathrm{C}$ allocation parameters are found to be key parameters in the original Biome-BGC model, in which model results were very sensitive to even a slight change in these parameters $[39,84]$. $\mathrm{C} / \mathrm{N}$ is mainly species specific, whereas $\mathrm{C}$ allocation is strongly dependent on tree species, and also environmental (i.e., site and climate) conditions [85]. Of several $C$ allocation parameters used in the model (Table A1), the ratio of fine root-to-leaf $C$ (FRC/LC) can be considered to be the most important for modelling of $\mathrm{SOC}_{30}$ stocks $[86,87]$. In dry soil conditions, as is frequently the case in the Mediterranean region, plants tend to allocate more $C$ into roots to reach soil water reservoirs and meet the plant's water demands [88]. By using a single LU-specific EPC list, with a unique FRC/LC ratio in all biogeographical regions, it is likely that for wetter and richer sites the ratio will be too high (resulting in an overestimation of SOC stocks), whereas for dryer and poorer sites, it is likely that the ratio will be too low (resulting in underestimation of SOC stocks). Our results (Figure 3) indicate that this may be one of the causes behind the model overestimation (Alpine and Continental) and underestimation (Mediterranean region) of $\mathrm{SOC}_{30}$ stocks in some LU. If so, it is likely that for the Alpine and the Continental region the FRC/LC parameter was, on average, probably too high, whereas for the Mediterranean region it was probably too low. Here it is also important to note that although the model shows good efficiency at the national LU level (Table 4), this apparent agreement may only be a fortunate compensation of two opposing biases, i.e., underestimation of $\mathrm{SOC}_{30}$ at the Mediterranean sites and overestimation of $\mathrm{SOC}_{30}$ at the Continental and the Alpine sites. This issue is still being investigated and the results will be presented in our future publications.

The strong bias of the model regarding different biogeographical regions is also reflected in the negative Nash-Sutcliff model efficacy (Table 4), which provides evidence against the use of the model on LUs stratified according to biogeographical regions. This confirms the need for improved model parameterisation, which will reflect not only speciesspecific differences, but also differences in ecophysiological traits that could be characteristic at the level of the biogeographical region.

At the plot level, the Biome-BGCMuSo model was not able to account for spatial variation in $\mathrm{SOC}_{30}$ stocks that originate from site-specific conditions, although the soil sub-model has been substantially improved regarding new processes and parameters for different soil layers [34]. Disagreement between measured and modelled soil carbon stocks at the plot level was previously observed in the original version of Biome-BGC [89]. For modelling at the plot level, reliable, long-term data on site management, disturbance and land-use changes are needed for improvement of the model performance at fine spatial variability. Because an accurate and comprehensive site history for each specific plot is difficult (or even impossible) to obtain, the issue of proper model initialisation [71] still hinders accurate reconstruction of SOC. A potential way forward is to explore the possibility of using a data assimilation method [90] to improve SOC estimates. Another issue is the limitation of the soils sampling. In addition to financial and other constraints that limit the number of soil samples that can be taken within a survey, soil sampling has, by its nature, a point-in-space characteristic, and although it is (if undertaken properly) representative of the area of the site, it probably does not equal the true mean of the $\mathrm{SOC}_{30}$ stock for the wider area of the site.

Uncertainty analysis implies estimating the model result uncertainty originating from different model inputs and/or different model parameters [91]. Estimating the uncertainty 
originating from model inputs for Biome-BGCMuSo would assume possessing more than one climate and soil database covering the entire area of the investigation (i.e., the whole national territory) [92]. Currently it is not the case in our study; therefore, it was not performed. Nevertheless, a recent study with Biome-BGCMuSo showed that the spatial variation in the SOC change rate is much larger than the variance in the SOC change rate originating from changes in model inputs (e.g., climate and soil data), for all investigated land uses (i.e., croplands, grasslands and forests) [92]. Accordingly, we can assume that the introduction of input data-related uncertainty at the plot level would not provide us with more information than we already obtained. Furthermore, estimating the uncertainty originating from model parameters is essential in modelling studies [93,94]; however, for the Biome-BGCMuSo model it would be an extensive task due to the high number of model parameters (i.e., 107). Nevertheless, sensitivity analysis is planned as part of the future work on Biome-BGCMuSo model calibration and validation. Finally, our results also indicate that the Biome-BGCMuSo model is still dominantly driven by meteorology, as is the case with the original Biome-BGC model [95]. Among various soil properties that cause spatial heterogeneity of SOC stocks, e.g., soil texture, bulk density, and soil aggregates, recent research shows that SOC is also strongly driven by mycorrhiza [96], microbial biomass [97] and soil fauna [98]. These processes are currently not considered within the Biome-BGCMuSo model. Therefore, in addition to model parameterisation, improvement of the model logic regarding specific processes and geological conditions should also be addressed in the future.

\section{Conclusions}

In this study, we focused on the estimation of $\mathrm{SOC}_{30}$ for Croatia using a process-based biogeochemical model. The study also introduced a new national soil survey dataset, which is consistent with the IPCC guidelines, and served as a reference for the first BiomeBGCMuSo model verification study of $\mathrm{SOC}_{30}$ at a large spatial scale in Central Europe. We demonstrated that the Biome-BGCMuSo model can reproduce the overall country mean of $\mathrm{SOC}_{30}$, but with considerable spatial variability. Although biases were present in different biogeographical regions that eventually compensated for each other, the study also highlighted that the overall, country-scale results of the equilibrium run were consistent with the observed means. Thus, no overall bias was found for the country means, which is a promising finding.

The results of the simulation of $\mathrm{SOC}_{30}$ in four different land-use categories (Deciduous forests, Coniferous forests, Annual croplands and Grasslands) at the national scale in Croatia indicate that additional calibration/adjustment regarding specific land uses is required, given that the spatial variability in $\mathrm{SOC}_{30}$ was not well reproduced. This can be partly attributed to the simplistic method that is used for the initialisation of the model, as the spin-up approach entirely ignores the site history. Note that, for the present modelling exercise, information on the past management was not available; thus, future studies should address this issue. From the perspective of the observations, there are also issues with the point-sampling method of the $\mathrm{SOC}_{30}$, where the effects of high spatial variability in soil become pronounced. These issues are very difficult to overcome at the national scale.

Model testing through model-data comparisons at different scales, such as the one presented in this work, highlights the main model issues and may serve as a guideline for improvement of model parameters or the internal model logic. A repeated soil survey is needed in order to assess the changes in $\mathrm{SOC}_{30}$ and to evaluate the potential of the Biome-BGCMuSo model for use in GHG reporting.

Supplementary Materials: The following are available online at https:/ / www.mdpi.com/article/10 .3390/land10090968/s1, Supplementary File 1: Database on measured and modelled soil organic carbon down to $30 \mathrm{~cm}$ at 573 plots in Croatia. 
Author Contributions: M.Z.O.S. and H.M. conceptualised the study and analysed the results; M.Z.O.S. run model simulations and wrote the first draft; A.K. provided meteorological data; Z.B. and D.H. provided support in modelling. Z.B., D.H., A.K., D.D., S.M., O.H., B.G. and H.M. reviewed, edited and improved the manuscript. M.Z.O.S., Z.B. and H.M. wrote the revised version. All authors have read and agreed to the published version of the manuscript.

Funding: The research was funded by the Croatian Science Foundation project MODFLUX (HRZZ IP-2019-04-6325). Z.B. was supported by the grant "Advanced research supporting the forestry and wood-processing sector's adaptation to global change and the 4th industrial revolution", No. CZ.02.1.01/0.0/0.0/16_019/0000803 financed by OP RDE. Z.B. and D.H. were supported by the Széchenyi 2020 program, the European Regional Development Fund and the Hungarian Government (GINOP-2.3.2-15-2016-00028). A.K. was supported by the Hungarian Scientific Research Fund (OTKA FK-128709) and by the János Bolyai Research Scholarship of the Hungarian Academy of Sciences (grant no. BO/00254/20/10). D.D. was supported by the "Young Researchers' Career Development Project-Training New Doctoral Students" financed by the Croatian Science Foundation (HRZZ DOK-2020-01-1407).

Data Availability Statement: The data presented in this study is available in the Supplementary Materials.

Acknowledgments: We thank Martina Šparica Miko from the Croatian Geological Survey for undertaking all of the soil organic carbon analysis, and Nikolina Ilijanić, Ivan Razum, Miljenko Marinac, Danijel Ivanišević, Goran Tijan and Nikolina Milanović for collecting the soil samples. We are grateful to three anonymous Reviewers and to the Academic Editor for their valuable comments that helped improve the manuscript.

Conflicts of Interest: The authors declare that they have no known competing financial interests or personal relationships that could have appeared to influence the work reported in this paper.

\section{Appendix A}

Table A1. List of ecophysiological parameters for the Biome-BGCMuSo v4.0 model used in this study. Values for Grassland, Cropland and Deciduous forest are from Hidy et al. (2016) [34], with some parameters adjusted according to specified references or proposed for the purpose of this study. Parameters for Coniferous forests are based on parameters for Deciduous forests and adjusted according to specified references. Superscripts in the Reference column refer to the vegetation type $\left({ }^{1}\right.$ Grassland, ${ }^{2}$ Cropland, ${ }^{3}$ Deciduous forest, ${ }^{4}$ Coniferous forest).

\begin{tabular}{|c|c|c|c|c|c|}
\hline \multirow{2}{*}{ Parameter Name } & \multicolumn{4}{|c|}{ Parameter Values } & \multirow{2}{*}{ References/Remarks } \\
\hline & Grassland (1) & Cropland (2) & Deciduous f. (3) & Coniferous f. (4) & \\
\hline $\begin{array}{l}\text { transfer growth } \\
\text { period as fraction } \\
\text { of growing season }\end{array}$ & 1 & 1 & 0.3 & 0.3 & \\
\hline $\begin{array}{l}\text { litterfall as fraction } \\
\text { of growing season }\end{array}$ & 1 & 1 & 0.3 & 0.3 & \\
\hline base temperature & 5 & 8 & 5 & 5 & $\begin{array}{l}\text { proposed value } \\
\text { (this study) }^{1}\end{array}$ \\
\hline $\begin{array}{l}\text { growing degree } \\
\text { day for start of } \\
\text { yield allocation }\end{array}$ & $\mathrm{N} / \mathrm{A}$ & 825 & 1000 & 1000 & \\
\hline $\begin{array}{l}\text { growing degree } \\
\text { day of start } \\
\text { genetically } \\
\text { programmed } \\
\text { senescence }\end{array}$ & $\mathrm{N} / \mathrm{A}$ & 1680 & 2350 & 2350 & \\
\hline $\begin{array}{l}\text { annual leaf and } \\
\text { fine root turnover } \\
\text { fract. }\end{array}$ & 1 & 1 & 1 & 0.25 & {$[67]^{4}$} \\
\hline $\begin{array}{l}\text { annual live wood } \\
\text { turnover fraction }\end{array}$ & $\mathrm{N} / \mathrm{A}$ & $\mathrm{N} / \mathrm{A}$ & 0.7 & 0.7 & \\
\hline
\end{tabular}


Table A1. Cont.

\begin{tabular}{|c|c|c|c|c|c|}
\hline \multirow{2}{*}{ Parameter Name } & \multicolumn{4}{|c|}{ Parameter Values } & \multirow{2}{*}{ References/Remark } \\
\hline & Grassland (1) & Cropland (2) & Deciduous f. (3) & Coniferous f. (4) & \\
\hline $\begin{array}{c}\text { annual } \\
\text { whole-plant } \\
\text { mortality fraction }\end{array}$ & 0.05 & 0.02 & 0.02 & 0.005 & {$[39]^{4}$} \\
\hline $\begin{array}{c}\text { annual fire } \\
\text { mortality fraction }\end{array}$ & 0 & 0 & 0 & 0 & \\
\hline $\begin{array}{l}\text { new fine root } C \text { : } \\
\text { new leaf } C\end{array}$ & 2.5 & 1.02 & 0.95 & 1 & $\begin{array}{l}\text { adjusted according } \\
\text { to }[63]^{1},[37]^{4}\end{array}$ \\
\hline $\begin{array}{c}\text { new fruit } C \text { : new } \\
\text { leaf } C\end{array}$ & 0 & 0.56 & 0.14 & 0 & $\begin{array}{l}\text { proposed value } \\
\text { (this study) }^{4}\end{array}$ \\
\hline $\begin{array}{c}\text { new softstem } C \text { : } \\
\text { new leaf } C\end{array}$ & 0.5 & 2.05 & $\mathrm{~N} / \mathrm{A}$ & $\mathrm{N} / \mathrm{A}$ & \\
\hline $\begin{array}{l}\text { new woody stem } \\
\text { C: new leaf C }\end{array}$ & $\mathrm{N} / \mathrm{A}$ & $\mathrm{N} / \mathrm{A}$ & 1.42 & 2.2 & {$[39]^{4}$} \\
\hline $\begin{array}{l}\text { new live wood } C \text { : } \\
\text { new total wood } C\end{array}$ & $\mathrm{~N} / \mathrm{A}$ & $\mathrm{N} / \mathrm{A}$ & 0.16 & 0.1 & {$[36]^{4}$} \\
\hline $\begin{array}{c}\text { new coarse root } C \text { : } \\
\text { new stem } C\end{array}$ & $\mathrm{~N} / \mathrm{A}$ & $\mathrm{N} / \mathrm{A}$ & 0.26 & 0.3 & {$[36]^{4}$} \\
\hline $\begin{array}{l}\text { current growth } \\
\text { proportion }\end{array}$ & 0.5 & 1 & 0.5 & 0.5 & $\begin{array}{l}\text { proposed value } \\
\text { (this study) }^{1}\end{array}$ \\
\hline $\mathrm{C}: \mathrm{N}$ of leaves & 25 & 38 & 24.5 & 42 & $\begin{array}{l}\text { adjusted according } \\
\text { to }[64]^{2},[39]^{4}\end{array}$ \\
\hline $\mathrm{C}: \mathrm{N}$ of leaf litter & 45 & 65 & 47.5 & 93 & {$[39]^{4}$} \\
\hline $\mathrm{C}: \mathrm{N}$ of fine roots & 50 & 42 & 43 & 58 & {$[39]^{4}$} \\
\hline $\mathrm{C}: \mathrm{N}$ of fruit & 25 & 50 & 33 & 0 & $\begin{array}{l}\text { proposed value } \\
\text { (this study) } 4\end{array}$ \\
\hline $\mathrm{C}: \mathrm{N}$ of softstem & 25 & 85 & $\mathrm{~N} / \mathrm{A}$ & $\mathrm{N} / \mathrm{A}$ & \\
\hline $\mathrm{C}: \mathrm{N}$ of live wood & $\mathrm{N} / \mathrm{A}$ & $\mathrm{N} / \mathrm{A}$ & 73.5 & 50 & {$[39]^{4}$} \\
\hline C:N of dead wood & $\mathrm{N} / \mathrm{A}$ & $\mathrm{N} / \mathrm{A}$ & 451 & 729 & {$[67]^{4}$} \\
\hline $\begin{array}{c}\text { leaf litter labile } \\
\text { proportion }\end{array}$ & 0.68 & 0.68 & 0.2 & 0.32 & {$[36]^{4}$} \\
\hline $\begin{array}{l}\text { leaf litter cellulose } \\
\text { proportion }\end{array}$ & 0.23 & 0.23 & 0.56 & 0.44 & {$[36]^{4}$} \\
\hline $\begin{array}{l}\text { fine root litter } \\
\text { labile proportion }\end{array}$ & 0.34 & 0.34 & 0.34 & 0.30 & {$[36]^{4}$} \\
\hline $\begin{array}{l}\text { fine root litter } \\
\text { cellulose } \\
\text { proportion }\end{array}$ & 0.44 & 0.44 & 0.44 & 0.45 & {$[36]^{4}$} \\
\hline $\begin{array}{l}\text { fruit litter labile } \\
\text { proportion }\end{array}$ & $\mathrm{N} / \mathrm{A}$ & 0.68 & 0.3 & 0 & $\begin{array}{l}\text { proposed value } \\
\text { (this study) }\end{array}$ \\
\hline $\begin{array}{l}\text { fruit litter cellulose } \\
\text { proportion }\end{array}$ & $\mathrm{N} / \mathrm{A}$ & 0.23 & 0.29 & 0 & $\begin{array}{l}\text { proposed value } \\
\text { (this study) }{ }^{4}\end{array}$ \\
\hline $\begin{array}{l}\text { softstem litter } \\
\text { labile proportion } \\
\text { softstem litter }\end{array}$ & 0.68 & 0.68 & $\mathrm{~N} / \mathrm{A}$ & $\mathrm{N} / \mathrm{A}$ & \\
\hline $\begin{array}{l}\text { cellulose } \\
\text { proportion }\end{array}$ & 0.23 & 0.23 & $\mathrm{~N} / \mathrm{A}$ & $\mathrm{N} / \mathrm{A}$ & \\
\hline $\begin{array}{l}\text { dead wood } \\
\text { cellulose } \\
\text { proportion }\end{array}$ & $\mathrm{N} / \mathrm{A}$ & $\mathrm{N} / \mathrm{A}$ & 0.75 & 0.76 & {$[36]^{4}$} \\
\hline
\end{tabular}


Table A1. Cont.

\begin{tabular}{|c|c|c|c|c|c|}
\hline \multirow{2}{*}{ Parameter Name } & \multicolumn{4}{|c|}{ Parameter Values } & \multirow{2}{*}{ References/Remarks } \\
\hline & Grassland (1) & Cropland (2) & Deciduous f. (3) & Coniferous f. (4) & \\
\hline $\begin{array}{l}\text { canopy water } \\
\text { interception } \\
\text { coefficient }\end{array}$ & 0.01 & 0.01 & 0.038 & 0.041 & {$[67]^{4}$} \\
\hline $\begin{array}{l}\text { canopy light } \\
\text { extinction } \\
\text { coefficient } \\
\text { all-sided to }\end{array}$ & 0.5 & 0.6 & 0.54 & 0.5 & $\begin{array}{c}\text { proposed value } \\
\text { (this study) }{ }^{1},[67]^{4}\end{array}$ \\
\hline $\begin{array}{l}\text { projected leaf area } \\
\text { ratio }\end{array}$ & 2 & 2 & 2 & 2.6 & {$[39]^{4}$} \\
\hline $\begin{array}{l}\text { canopy average } \\
\text { specific leaf area } \\
\text { ratio of shaded }\end{array}$ & 49 & 43.3 & 34.5 & 12 & {$[67]^{4}$} \\
\hline $\begin{array}{c}\text { specific leaf } \\
\text { area:sunlit specific } \\
\text { leaf area }\end{array}$ & 2 & 2 & 2 & 2 & \\
\hline $\begin{array}{l}\text { fraction of leaf } \mathrm{N} \\
\text { in Rubisco }\end{array}$ & 0.2 & 0.39 & 0.088 & 0.04 & $\begin{array}{c}\text { proposed value } \\
\text { (this study) })^{1,2},[67]\end{array}$ \\
\hline $\begin{array}{l}\text { fraction of leaf } \mathrm{N} \\
\text { in PeP carboxylase }\end{array}$ & $\mathrm{N} / \mathrm{A}$ & 0.03 & $\mathrm{~N} / \mathrm{A}$ & $\mathrm{N} / \mathrm{A}$ & \\
\hline $\begin{array}{l}\text { maximum } \\
\text { stomatal } \\
\text { conductance }\end{array}$ & 0.004 & 0.012 & 0.0024 & 0.003 & $\begin{array}{c}\text { proposed value } \\
\text { (this study) }{ }^{1},[36]^{4}\end{array}$ \\
\hline $\begin{array}{l}\text { cuticular } \\
\text { conductance }\end{array}$ & 0.00006 & 0.00006 & 0.00006 & 0.00001 & {$[36]^{4}$} \\
\hline $\begin{array}{l}\text { boundary layer } \\
\text { conductance }\end{array}$ & 0.04 & 0.04 & 0.005 & 0.08 & {$[36]^{4}$} \\
\hline $\begin{array}{l}\text { relative soil water } \\
\text { content limitation1 } \\
\text { (proportion to field } \\
\text { capacity value) }\end{array}$ & 1 & 1 & 1 & 1 & $\begin{array}{l}\text { proposed value } \\
\text { (this study) })^{3,4}\end{array}$ \\
\hline $\begin{array}{l}\text { relative soil water } \\
\text { content limitation } \\
2 \text { (proportion to } \\
\text { saturation capacity } \\
\text { value) }\end{array}$ & 0.99 & 0.99 & 1 & 1 & $\begin{array}{l}\text { proposed value } \\
\text { (this study) }{ }^{3,4}\end{array}$ \\
\hline $\begin{array}{l}\text { vapour pressure } \\
\text { deficit: start of } \\
\text { conductance } \\
\text { reduction }\end{array}$ & 1000 & 1000 & 200 & 930 & {$[67]^{4}$} \\
\hline $\begin{array}{l}\text { vapour pressure } \\
\text { deficit: complete } \\
\text { conductance } \\
\text { reduction } \\
\text { senescence }\end{array}$ & 5000 & 5000 & 2550 & 4100 & $\begin{array}{c}\text { proposed value } \\
\text { (this study) }{ }^{1},[67]^{4}\end{array}$ \\
\hline $\begin{array}{c}\text { mortality } \\
\text { coefficient of } \\
\text { aboveground plant } \\
\text { material }\end{array}$ & 0.05 & 0.05 & 0.01 & 0 & $\begin{array}{l}\text { proposed value } \\
\text { (this study) }\end{array}$ \\
\hline $\begin{array}{c}\text { senescence } \\
\text { mortality } \\
\text { coefficient of } \\
\text { belowground plant } \\
\text { material }\end{array}$ & 0.01 & 0.01 & 0.01 & 0 & $\begin{array}{l}\text { proposed value } \\
\text { (this study) }\end{array}$ \\
\hline
\end{tabular}


Table A1. Cont.

\begin{tabular}{|c|c|c|c|c|c|}
\hline \multirow{2}{*}{ Parameter Name } & \multicolumn{4}{|c|}{ Parameter Values } & \multirow{2}{*}{ References/Remark } \\
\hline & Grassland (1) & Cropland (2) & Deciduous f. (3) & Coniferous f. (4) & \\
\hline genetically & & & & & \\
\hline $\begin{array}{l}\text { programmed } \\
\text { senescence } \\
\text { mortality } \\
\text { coefficient of leaf }\end{array}$ & 0 & 0.1 & 0.025 & 0 & $\begin{array}{l}\text { proposed value } \\
\text { (this study) }\end{array}$ \\
\hline $\begin{array}{l}\text { turnover rate of } \\
\text { wilted standing } \\
\text { biomass to litter }\end{array}$ & 0.01 & 0.001 & 0.01 & 0.01 & $\begin{array}{l}\text { proposed value } \\
\text { (this study) }{ }^{1}\end{array}$ \\
\hline $\begin{array}{l}\text { turnover rate of } \\
\text { cut-down } \\
\text { non-woody } \\
\text { biomass to litter }\end{array}$ & 0.05 & 0.01 & 0.05 & 0.05 & $\begin{array}{l}\text { proposed value } \\
\text { (this study) }^{1}\end{array}$ \\
\hline $\begin{array}{l}\text { N denitrification } \\
\text { proportion } \\
\text { bulk } \mathrm{N}\end{array}$ & 0.01 & 0.01 & 0.01 & 0.01 & \\
\hline $\begin{array}{l}\text { denitrification } \\
\text { proportion, wet } \\
\text { case }\end{array}$ & 0.005 & 0.005 & 0.02 & 0.02 & $\begin{array}{l}\text { proposed value } \\
\text { (this study) }^{1,2}\end{array}$ \\
\hline $\begin{array}{c}\text { bulk } \mathrm{N} \\
\text { denitrification } \\
\text { proportion, dry } \\
\text { case }\end{array}$ & 0.001 & 0.001 & 0.01 & 0.01 & $\begin{array}{l}\text { proposed value } \\
\text { (this study) }^{1,2}\end{array}$ \\
\hline $\begin{array}{c}\text { mobile } \mathrm{N} \\
\text { proportion } \\
\text { (leaching) }\end{array}$ & 0.1 & 0.1 & 0.1 & 0.1 & \\
\hline $\begin{array}{l}\text { symbiotic+asymbiotic } \\
\text { fixation of } \mathrm{N}\end{array}$ & 0.003 & 0.0005 & 0.0036 & 0.0016 & $\begin{array}{c}\text { adjusted according } \\
\text { to }[65,66]^{1},[65]^{4}\end{array}$ \\
\hline $\begin{array}{c}\text { ratio of storage } \\
\text { and actual pool } \\
\text { mortality due to } \\
\text { management }\end{array}$ & 0.1 & 0.1 & 0.9 & 0.9 & \\
\hline $\begin{array}{c}\text { critical value of } \\
\text { soilstress } \\
\text { coefficient }\end{array}$ & 0.3 & 0.4 & 0.5 & 0.3 & $\begin{array}{l}\text { proposed value } \\
\text { (this study) })^{1,4}\end{array}$ \\
\hline $\begin{array}{l}\text { critical number of } \\
\text { stress days }\end{array}$ & 60 & 60 & 90 & 90 & \\
\hline $\begin{array}{l}\text { maximum depth of } \\
\text { rooting zone }\end{array}$ & $0.1-0.63$ & $0.1-0.63$ & $0.1-0.63$ & $0.1-0.63$ & plot-specific \\
\hline $\begin{array}{l}\text { root distribution } \\
\text { parameter }\end{array}$ & 3.67 & 3.67 & 3.67 & 3.67 & \\
\hline $\begin{array}{c}\text { maturity } \\
\text { coefficient } \\
\text { growth respiration }\end{array}$ & 0.5 & 0.5 & 0.5 & 0.5 & \\
\hline $\begin{array}{l}\text { per unit of } C \\
\text { grown } \\
\text { maintenance }\end{array}$ & 0.3 & 0.3 & 0.3 & 0.3 & \\
\hline $\begin{array}{c}\text { respiration in } \\
\mathrm{kgC} / \text { day per } \mathrm{kg} \text { of } \\
\text { tissue } \mathrm{N}\end{array}$ & 0.218 & 0.218 & 0.4 & 0.4 & \\
\hline
\end{tabular}


Table A2. Description of management activities for different land-use categories simulated with the Biome-BGCMuSo model.

\begin{tabular}{|c|c|c|c|}
\hline Land-Use Category & Management Activity & DOY & Description \\
\hline $\begin{array}{l}\text { Deciduous forests } \\
\text { Coniferous forests }\end{array}$ & Thinning * & 30 & $\begin{array}{c}2.1 \% \mathrm{y}^{-1} \\
3 \% \mathrm{y}^{-1}\end{array}$ \\
\hline \multirow[t]{2}{*}{ Grassland } & fertilising & 100,190 & $\begin{array}{c}30+30 \mathrm{~kg} \mathrm{~N} \mathrm{ha} \mathrm{N}^{-1} \mathrm{y}^{-1} \\
\text { animal manure }(2 \% \mathrm{~N}, 40 \% \mathrm{C})\end{array}$ \\
\hline & Mowing & 150,200 & $75 \%$ plant material \\
\hline \multirow{4}{*}{ Annual cropland } & Planting & 105 & $25 \mathrm{~kg} \mathrm{ha}^{-1}$ \\
\hline & fertilising & $91,145,288$ & $\begin{array}{c}60+40+50 \mathrm{~kg} \mathrm{~N} \mathrm{ha}^{-1} \mathrm{y}^{-1} \\
70 \% \text { chemical fertiliser }(47 \% \\
\mathrm{N}, 5 \% \mathrm{C}) \\
30 \% \text { animal manure }\end{array}$ \\
\hline & Harvesting & 273 & $50 \%$ plant material \\
\hline & Ploughing & 300 & down to $30 \mathrm{~cm}$ \\
\hline
\end{tabular}

* Deciduous forests in Croatia are even-aged managed, with thinnings of $15 \%$ performed every 10 years and with regeneration cuts ( $2-3$ cuts) performed during the last 10 years of the rotation period. In order to perform spatial modelling, we needed thinnings and regeneration cuts distributed among different locations. In the absence of this information, we estimated average annual thinning intensity to ensure evenly distributed thinning at the spatial scale. If we assume a rotation period of 140 years (i.e., prescribed rotation for pedunculate oak), annual thinning intensity should account for $1.5 \%$ thinning rate during a 130 year period and $100 \%$ regeneration cut during whole rotation period, which sums to $2.1 \%$. Coniferous forests are uneven-aged managed with thinning of $30 \%$ performed every 10 years, i.e., average annual thinning intensity is $3 \%$.

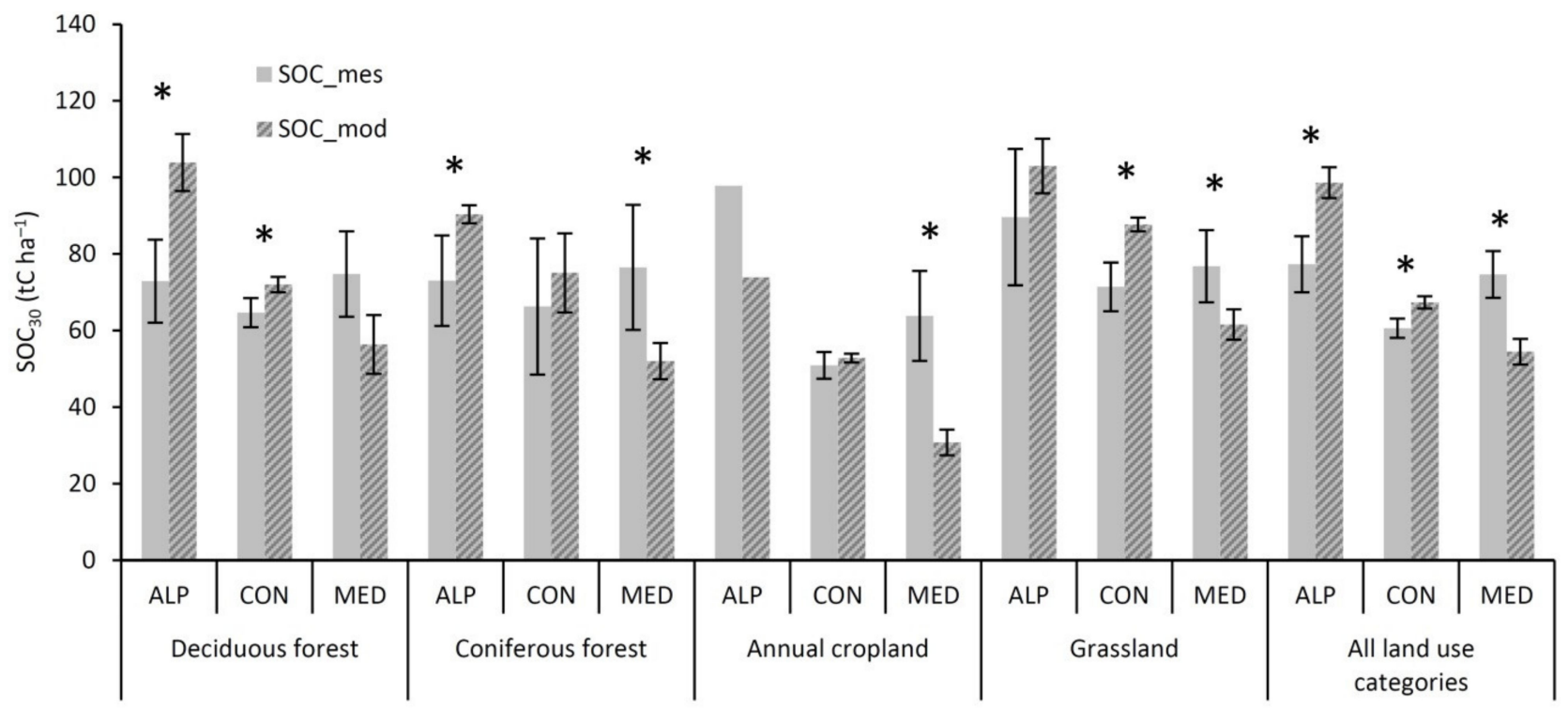

Figure A1. Comparison of measured and modelled soil organic carbon stocks down to $30 \mathrm{~cm}$ in different land-use categories with respect to biogeographical regions. Asterisk indicates statistically significant difference $(p<0.01)$ between measured and modelled data at the land use $\times$ biogeographical region level. 

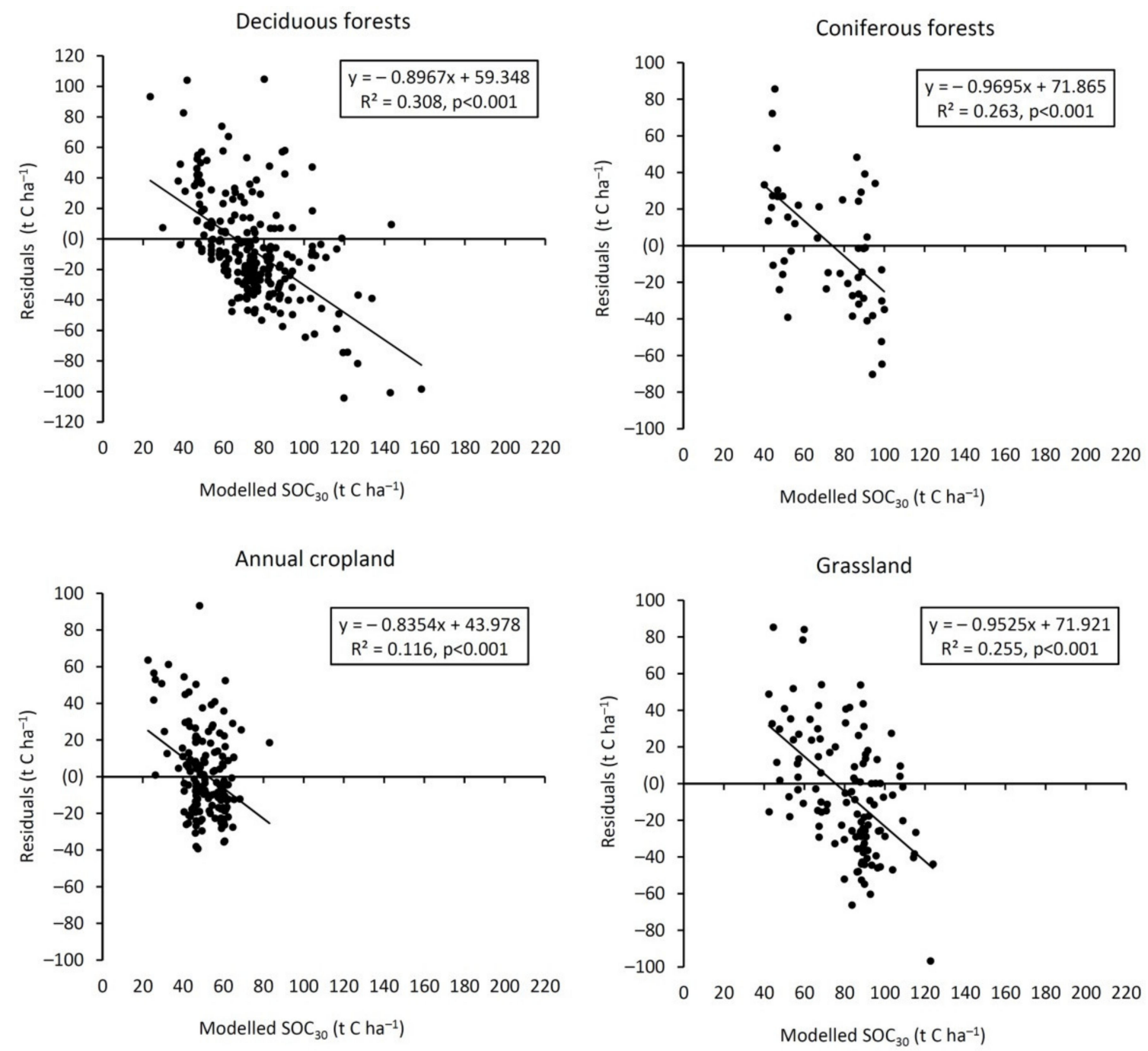

Figure A2. Residual analysis for different land-use categories.

\section{References}

1. UN (United Nations). Kyoto Protocol to the United Nations Framework Convention on Climate Change; United Nations: Kyoto, Japan, 1997; pp. 1-21. Available online: https:/ / unfccc.int/resource/docs/cop3/07a01.pdf (accessed on 23 July 2021).

2. UN (United Nations). Paris Agreement; United Nations: Paris, France, 2015; pp. 1-27. Available online: https://undocs.org/en/ FCCC/CP/2015/10/Add.1 (accessed on 23 July 2021).

3. EC (European Commission). Communication from the Commission to the European Parliament, the European Council, the Council, the European Economic and Social Committee and the Committee of the Regions-The European Green Deal; European Commission: Brussels, Belgium, 2019; pp. 1-24.

4. Batjes, N.H. Total C and N in soils of the world. Eur. J. Soil Sci. 1996, 47, 151-163. [CrossRef]

5. Scharlemann, J.P.W.; Tanner, E.V.J.; Hiederer, R.; Kapos, V. Global soil carbon: Understanding and managing the largest terrestrial carbon pool. Carbon Manag. 2014, 5, 81-91. [CrossRef]

6. Crowther, T.W.; Todd-Brown, K.E.O.; Rowe, C.W.; Wieder, W.R.; Carey, J.C.; Machmuller, M.B.; Snoek, B.L.; Fang, S.; Zhou, G.; Allison, S.D.; et al. Quantifying global soil carbon losses in response to warming. Nature 2016, 540, 104-108. [CrossRef] [PubMed]

7. Rustad, L.E.; Campbell, J.L.; Marion, G.M.; Norby, R.J.; Mitchell, M.J.; Hartley, A.E.; Cornelissen, J.H.C.; Gurevitch, J. Gcte-News. A meta-analysis of the response of soil respiration, net nitrogen mineralization, and aboveground plant growth to experimental ecosystem warming. Oecologia 2001, 126, 543-562. [CrossRef] [PubMed]

8. Melillo, J.M.; Steudler, P.A.; Aber, J.D.; Newkirk, K.; Lux, H.; Bowles, F.P.; Catricala, C.; Magill, A.; Ahrens, T.; Morrisseau, S. Soil warming and carbon-cycle feedbacks to the climate system. Science 2002, 298, 2173-2176. [CrossRef] [PubMed]

9. Fyson, C.L.; Jeffery, M.L. Ambiguity in the land use component of mitigation contributions toward the Paris agreement goals. Earths Future 2019, 7, 873-891. [CrossRef] 
10. IPCC GPG (The Intergovernmental Panel on Climate Change Good Practice Guidelines). Guidelines for National Greenhouse Gas Inventories; Eggleston, H.S., Buendia, L., Miwa, K., Ngara, T., Tanabe, K., Eds.; National Greenhouse Gas Inventories Programme, IGES: Kanagawa, Japan, 2006.

11. Jenkinson, D.S.; Coleman, K. The turnover of organic carbon in subsoils. Part 2. Modelling carbon turnover. Eur. J. Soil Sci. 2008, 59, 400-413. [CrossRef]

12. UK NIR. United Kingdom National Inventory Report 2020. Available online: https://unfccc.int/documents/225987 (accessed on 23 July 2021).

13. Liski, J.; Palosuo, T.; Peltoniemi, M.; Sievanen, R. Carbon and decomposition model Yasso for forest soils. Ecol. Modell. 2005, 189, 168-182. [CrossRef]

14. Alvaro-Fuentes, J.; Easter, M.; Cantero-Martinez, C.; Paustian, K. Modelling soil organic carbon stocks and their changes in the northeast of Spain. Eur. J. Soil Sci. 2011, 62, 685-695. [CrossRef]

15. CH NIR. Swiss National Inventory Report 2020. Available online: https://unfccc.int/documents/224855 (accessed on 23 July 2021).

16. FI NIR. Finnish National Inventory Report 2020. Available online: https://unfccc.int/documents/219060 (accessed on 23 July 2021).

17. Parton, J.W. The century model. In Evaluation of Soil Organic Matter Models; Powlson, D.S., Smith, P., Smith, J.U., Eds.; Springer: Berlin/Heidelberg, Germany, 1996; pp. 283-291.

18. Falloon, P.; Smith, P. Accounting for changes in soil carbon under the Kyoto Protocol: Need for improved long-term data sets to reduce uncertainty in model projections. Soil Use Manag. 2003, 19, 265-269. [CrossRef]

19. Hararuk, O.; Xia, J.Y.; Luo, Y.Q. Evaluation and improvement of a global land model against soil carbon data using a Bayesian Markov chain Monte Carlo method. J. Geophys. Res. Biogeosci. 2014, 119, 403-417. [CrossRef]

20. Tupek, B.; Launiainen, S.; Peltoniemi, M.; Sievanen, R.; Perttunen, J.; Kulmala, L.; Penttila, T.; Lindroos, A.J.; Hashimoto, S.; Lehtonen, A. Evaluating CENTURY and Yasso soil carbon models for $\mathrm{CO}_{2}$ emissions and organic carbon stocks of boreal forest soil with Bayesian multi-model inference. Eur. J. Soil Sci. 2019, 70, 847-858.

21. Luo, Y.; Zhou, X. Soil Respiration and the Environment; Elsevier: Amsterdam, The Netherlands, 2006; p. 316.

22. Campbell, E.E.; Paustian, K. Current developments in soil organic matter modelling and the expansion of model applications: A review. Environ. Res. Lett. 2015, 10, 123004. [CrossRef]

23. Parton, W.; Del Grosso, S.J.; Plante, A.F.; Adair, E.C.; Lutz, S.M. Modelling the dynamics of soil organic matter and nutrient cycling. In Soil Microbiology, Ecology, and Biochemistry, 4th ed.; Paul, E.A., Ed.; Elsevier: Amsterdam, The Netherlands, 2015; pp. 505-537.

24. Keel, S.G.; Leifeld, J.; Mayer, J.; Taghizadeh-Toosi, A.; Olesen, J.E. Large uncertainty in soil carbon modelling related to method of calculation of plant carbon input in agricultural systems. Eur. J. Soil Sci. 2017, 68, 953-963. [CrossRef]

25. Ostle, N.J.; Levy, P.E.; Evans, C.D.; Smith, P. UK land use and soil carbon sequestration. Land Use Policy 2009, 26, S274-S283. [CrossRef]

26. Poeplau, C.; Don, A.; Vesterdal, L.; Leifeld, J.; Van Wesemael, B.; Schumacher, J.; Gensior, A. Temporal dynamics of soil organic carbon after land-use change in the temperate zone-carbon response functions as a model approach. Glob. Change Biol. 2011, 17, 2415-2427. [CrossRef]

27. Johnson, D.W.; Curtis, P.S. Effects of forest management on soil C and N storage: Meta analysis. For. Ecol Manag. 2001, 140, 227-238. [CrossRef]

28. Chen, L.C.; Wang, S.L.; Wang, Q.K. Ecosystem carbon stocks in a forest chronosequence in Hunan Province, South China. Plant Soil 2016, 409, 217-228. [CrossRef]

29. Ostrogović Sever, M.Z.; Alberti, G.; Delle Vedove, G.; Marjanović, H. Temporal Evolution of carbon stocks, fluxes and carbon balance in pedunculate oak chronosequence under close-to-nature forest management. Forests 2019, 10, 814. [CrossRef]

30. Smith, J.; Smith, P.; Wattenbach, M.; Zaehle, S.; Hiederer, R.; Jones, R.J.A.; Montanarella, L.; Rounsevell, M.D.A.; Reginster, I.; Ewert, F. Projected changes in mineral soil carbon of European croplands and grasslands, 1990-2080. Glob. Change Biol. 2005, 11, 2141-2152. [CrossRef]

31. Mondini, C.; Coleman, K.; Whitmore, A.P. Spatially explicit modelling of changes in soil organic C in agricultural soils in Italy, 2001-2100: Potential for compost amendment. Agric. Ecosyst. Environ. 2012, 153, 24-32. [CrossRef]

32. Munoz-Rojas, M.; Jordan, A.; Zavala, L.M.; Gonzalez-Penaloza, F.A.; De la Rosa, D.; Pino-Mejias, R.; Anaya-Romero, M. Modelling soil organic carbon stocks in global change scenarios: A CarboSOIL application. Biogeosciences 2013, 10, 8253-8268. [CrossRef]

33. Running, S.W.; Hunt, E.R.J. Generalization of a forest ecosystem process model for other biomes, BIOME-BGC, and an application for global-scale models. In Scaling Physiological Processes: Leaf to Globe; Ehleringer, J.R., Field, C., Eds.; Academic Press: San Diego, CA, USA, 1993; pp. 141-158.

34. Hidy, D.; Barcza, Z.; Marjanovic, H.; Sever, M.Z.O.; Dobor, L.; Gelybo, G.; Fodor, N.; Pinter, K.; Churkina, G.; Running, S.; et al. Terrestrial ecosystem process model Biome-BGCMuSo v4.0: Summary of improvements and new modeling possibilities. Geosci. Model Dev. 2016, 9, 4405-4437. [CrossRef]

35. Pietsch, S.A.; Hasenauer, H. Using mechanistic modeling within forest ecosystem restoration. For. Ecol. Manag. 2002, 159, 111-131. [CrossRef] 
36. Bond-Lamberty, B.; Gower, S.T.; Ahl, D.E.; Thornton, P.E. Reimplementation of the Biome-BGC model to simulate successional change. Tree Physiol. 2005, 25, 413-424. [CrossRef] [PubMed]

37. Cienciala, E.; Tatarinov, F.A. Application of BIOMEBGC model to managed forests. 2. Comparison with longterm observations of stand production for major tree species. For. Ecol. Manag. 2006, 237, 252-266. [CrossRef]

38. Hidy, D.; Barcza, Z.; Haszpra, L.; Churkina, G.; Pinter, K.; Nagy, Z. Development of the Biome-BGC model for simulation of managed herbaceous ecosystems. Ecol. Model 2012, 226, 99-119. [CrossRef]

39. White, M.; Thornton, P.E.; Running, S.W.; Nemani, R.R. Parameterization and sensitivity analysis of the BIOME-BGC terrestrial ecosystem model: Net primary production controls. Earth Interact. 2000, 4, 1-85. [CrossRef]

40. Pietsch, S.A.; Hasenauer, H.; Thornton, P.E. BGC-model parameters for tree species growing in central European forests. For. Ecol. Manag. 2005, 211, 264-295. [CrossRef]

41. Trusilova, K.; Trembath, J.; Churkina, G. Parameter Estimation and Validation of the Terrestrial Ecosystem Model Biome-Bgc Using Eddy-Covariance Flux Measurements; MPI for Biogeochemistry: Jena, Germany, 2010; Volume 2009.

42. Wu, Y.; Wang, X.; Ouyang, S.; Xu, K.; Hawkins, B.A.; Sun, O.J. A test of Biome-BGC with dendrochronology for forests along the altitudinal gradient of Mt. Changbai in northeast. Chin. J. Plant Ecol. 2017, 10, 415-425. [CrossRef]

43. Hlasny, T.; Barcza, Z.; Fabrika, M.; Balazs, B.; Churkina, G.; Pajtik, J.; Sedmak, R.; Turcani, M. Climate change impacts on growth and carbon balance of forests in Central Europe. Clim. Res. 2011, 47, 219-236. [CrossRef]

44. Han, Q.F.; Luo, G.P.; Li, C.F.; Shakir, A.; Wu, M.; Saidov, A. Simulated grazing effects on carbon emission in Central Asia. Agric. For. Meteorol. 2016, 216, 203-214. [CrossRef]

45. Hartig, F.; Dyke, J.; Hickler, T.; Higgins, S.I.; O’Hara, R.B.; Scheiter, S.; Huth, A. Connecting dynamic vegetation models to data-an inverse perspective. J. Biogeogr. 2012, 39, 2240-2252. [CrossRef]

46. Sitch, S.; Smith, B.; Prentice, I.C.; Arneth, A.; Bondeau, A.; Cramer, W.; Kaplan, J.O.; Levis, S.; Lucht, W.; Sykes, M.T.; et al. Evaluation of ecosystem dynamics, plant geography and terrestrial carbon cycling in the LPJ dynamic global vegetation model. Glob. Change Biol. 2003, 9, 161-185. [CrossRef]

47. Lasch-Born, P.; Suckow, F.; Reyer, C.P.O.; Gutsch, M.; Kollas, C.; Badeck, F.W.; Bugmann, H.K.M.; Grote, R.; Furstenau, C.; Lindner, M.; et al. Description and evaluation of the process-based forest model 4C v2.2 at four European forest sites. Geosci. Model Dev. 2020, 13, 5311-5343. [CrossRef]

48. AT NIR. Austrian National Inventory Report 2020. Available online: https:/ / unfccc.int/documents/226418 (accessed on 23 July 2021).

49. Bai, J.W.; Shen, Z.Y.; Yan, T.Z. A comparison of single-and multi-site calibration and validation: A case study of SWAT in the Miyun Reservoir watershed, China. Front. Earth Sci. 2017, 11, 592-600. [CrossRef]

50. Forrester, D.I.; Hobi, M.L.; Mathys, A.S.; Stadelmann, G.; Trotsiuk, V. Calibration of the process-based model 3-PG for major central European tree species. Eur. J. For. Res. 2021, 140, 1-22. [CrossRef]

51. EEA (European Environmental Agency). Biogeographical Regions in Europe; EEA: Copenhagen, Denmark, 2016; Available online: https:/ / www.eea.europa.eu/data-and-maps/figures/biogeographical-regions-in-europe-2 (accessed on 23 July 2021).

52. Zaninović, K.; Gajić-Čapka, M.; Perčec Tadić, M.; Vučetić, M.; Milković, J.; Bajić, A.; Cindrić, K.; Cvitan, L.; Katušin, Z.; Kaučić, D.; et al. Climate Atlas of Croatia 1961-1990, 1971-2000; Meteorological and Hydrological Service: Zagreb, Croatia, 2008 ; p. 200.

53. Seletković, Z.; Katušin, Z. Climate of Croatia. In Forests of Croatia; Rauš, Đ., Ed.; Faculty of Forestry, University of Zagreb, Croatian Forests Ltd.: Zagreb, Croatia, 1992; pp. 13-18.

54. Bogunović, M.; Vidaček, Ž.; Racz, Z.; Husnjak, S.; Sraka, M. The practical aspects of soil suitability map of Croatia. Agron. Glas. 1997, 59, 363-399. Available online: https://hrcak.srce.hr/147226 (accessed on 23 July 2021).

55. Bašić, F.; Bogunović, M.; Božić, M.; Husnjak, S.; Jurić, I.; Kisić, I.; Mesić, M.; Mirošević, N.; Romić, D.; Žugec, I. Regionalisation of Croatian agriculture. Agric. Conspec. Sci. 2007, 72, 27-38.

56. Velić, I.; Vlahović, I. Explanatory Notes of the Geological Map of the Republic of Croatia in 1:300,000 Scale; Croatian Geological Survey: Zagreb, Croatia, 2009; p. 147.

57. Halamić, J.; Miko, S. Geochemical Atlas of the Republic of Croatia; Croatian Geological Survey: Zagreb, Croatia, 2009 ; p. 87.

58. Croatian Forests Ltd. Forest Management Area Plan for the Republic of Croatia for the Period 2016-2025; Croatian Forests Ltd: Zagreb, Croatia, 2016; Available online: https://poljoprivreda.gov.hr/istaknute-teme/sume-112/sumarstvo/sumskogospodarskaosnova-2016-2025/250 (accessed on 23 July 2021).

59. HR NIR. Croatian National Inventory Report 2020. Available online: https://unfccc.int/documents/223243 (accessed on 23 July 2021).

60. Koven, C.D.; Riley, W.J.; Subin, Z.M.; Tang, J.Y.; Torn, M.S.; Collins, W.D.; Bonan, G.B.; Lawrence, D.M.; Swenson, S.C. The effect of vertically resolved soil biogeochemistry and alternate soil C and N models on C dynamics of CLM4. Biogeosciences 2013, 10, 7109-7131. [CrossRef]

61. Falloon, P.D.; Smith, P. Modelling refractory soil organic matter. Biol. Fertil. Soils 2000, 30, 388-398.

62. Dobor, L.; Barcza, Z.; Hlasny, T.; Havasi, A.; Horvath, F.; Ittzes, P.; Bartholy, J. Bridging the gap between climate models and impact studies: The FORESEE Database. Geosci. Data J. 2014, 2, 1-11. [CrossRef] [PubMed]

63. Dalrymple, R.L.; Dwyer, D.D. Root and shoot growth of five range grasses. J. Range Manag. 1967, 20, 141-145. [CrossRef]

64. Barbosa, J.Z.; Ferreira, C.F.; dos Santos, N.Z.; Motta, A.C.V.; Prior, S.; Gabardo, J. Production, carbon and nitrogen in stover fractions of corn (Zea mays L.) in response to cultivar development. Cienc. Agrotecnologia 2016, 40, 665-675. [CrossRef] 
65. Cleveland, C.C.; Townsend, A.R.; Schimel, D.S.; Fisher, H.; Howarth, R.W.; Hedin, L.O.; Perakis, S.S.; Latty, E.F.; Von Fischer, J.C.; Elseroad, A.; et al. Global patterns of terrestrial biological nitrogen (N-2) fixation in natural ecosystems. Glob. Biogeochem. Cycles 1999, 13, 623-645. [CrossRef]

66. Butler, G.J.; Christian, T.; Schwenke, G.D.; Herridge, D.F. Nitrogen fixation inputs from lucerne-dominated pastures in the Central-East of NSW. In Farming Systems, Proceedings of the 10th Agronomy Conference, Hobart, TAS, Australia, 21 January-1 February 2001; Rowe, B., Donaghy, D., Mendham, N., Eds.; Agronomy Australia Proceedings: Toowoomba, Australia, 2001; Available online: http:/ / www.agronomyaustraliaproceedings.org/images/sampledata/2001/p/1/butler.pdf (accessed on 23 July 2021).

67. Thornton, P.E.; Running, S.W.; Hunt, E.R. Biome-BGC: Terrestrial Ecosystem Process Model, Version 4.1.1; ORNL DAAC: Oak Ridge, TN, USA, 2005; Available online: https:/ /daac.ornl.gov/cgi-bin/dsviewer.pl?ds_id=805 (accessed on 23 July 2021).

68. Mauna Loa Observatory. Available online: http://www.esrl.noaa.gov/gmd/obop/mlo/ (accessed on 23 July 2021).

69. Etheridge, D.M.; Steele, L.P.; Langenfelds, R.L.; Francey, R.J.; Barnola, J.M.; Morgan, V.I. Natural and anthropogenic changes in atmospheric $\mathrm{CO}_{2}$ over the last 1000 years from air in Antarctic ice and firn. J. Geophys. Res. Atmos. 1996, 101, 4115-4128. [CrossRef]

70. Churkina, G.; Brovkin, V.; von Bloh, W.; Trusilova, K.; Jung, M.; Dentener, F. Synergy of rising nitrogen depositions and atmospheric $\mathrm{CO}_{2}$ on land carbon uptake moderately offsets global warming. Glob. Biogeochem. Cycles 2009, 23, GB4027. [CrossRef]

71. Thornton, P.E.; Rosenbloom, N.A. Ecosystem model spin-up: Estimating steady state conditions in a coupled terrestrial carbon and nitrogen cycle model. Ecol. Model 2005, 189, 25-48. [CrossRef]

72. Hidy, D.; Barcza, Z.; Thornton, P.; Running, S. User's Guide for Biome-BGC MuSo 4.0. 2016. Available online: http:/ / nimbus.elte. hu/bbgc/files/Manual_BBGC_MuSo_v4.0.pdf (accessed on 23 July 2021).

73. Ostrogović Sever, M.Z.; Paladinić, E.; Barcza, Z.; Hidy, D.; Kern, A.; Anić, M.; Marjanović, H. Biogeochemical Modelling vs. tree-ring measurements-comparison of growth dynamic estimates at two distinct oak forests in Croatia. South-East Eur. For. 2017, 8, 71-84. [CrossRef]

74. Thornton, P.E.; Law, B.E.; Gholz, H.L.; Clark, K.L.; Falge, E.; Ellsworth, D.S.; Golstein, A.H.; Monson, R.K.; Hollinger, D.; Falk, M.; et al. Modeling and measuring the effects of disturbance history and climate on carbon and water budgets in evergreen needleleaf forests. Agric. For. Meteorol. 2002, 113, 185-222. [CrossRef]

75. Merganicova, K.; Pietsch, S.A.; Hasenauer, H. Testing mechanistic modeling to assess impacts of biomass removal. For. Ecol. Manag. 2005, 207, 37-57. [CrossRef]

76. Chiesi, M.; Maselli, F.; Moriondo, M.; Fibbi, L.; Bindi, M.; Running, S.W. Application of BIOME-BGC to simulate Mediterranean forest processes. Ecol. Model 2007, 206, 179-190. [CrossRef]

77. Ueyama, M.; Ichii, K.; Hirata, R.; Takagi, K.; Asanuma, J.; Machimura, T.; Nakai, Y.; Ohta, T.; Saigusa, N.; Takahashi, Y.; et al. Simulating carbon and water cycles of larch forests in East Asia by the BIOME-BGC model with AsiaFlux data. Biogeosciences 2010, 7, 959-977. [CrossRef]

78. Maselli, F.; Chiesi, M.; Brilli, L.; Moriondo, M. Simulation of olive fruit yield in Tuscany through the integration of remote sensing and ground data. Ecol. Model 2012, 244, 1-12. [CrossRef]

79. Morais, T.G.; Teixeira, R.F.M.; Domingos, T. Detailed global modelling of soil organic carbon in cropland, grassland and forest soils. PLoS ONE 2019, 14, e0222604. [CrossRef] [PubMed]

80. Bakker, M.M.; Hatna, E.; Kuhlman, T.; Mucher, C.A. Changing environmental characteristics of European cropland. Agric. Syst. 2011, 104, 522-532. [CrossRef]

81. Smith, W.K.; Hinckley, T.M. Ecophysiology of Coniferous Forests, 1st ed.; Academic Press: San Diego, CA, USA, $1995 ;$ p. 338.

82. Muller, T.; Hoper, H. Soil organic matter turnover as a function of the soil clay content: Consequences for model applications. Soil Biol. Biochem. 2004, 36, 877-888. [CrossRef]

83. Rasse, D.P.; Rumpel, C.; Dignac, M.F. Is soil carbon mostly root carbon? Mechanisms for a specific stabilisation. Plant Soil 2005, 269, 341-356. [CrossRef]

84. Tatarinov, F.A.; Cienciala, E. Application of BIOME-BGC model to managed forests 1. Sensitivity analysis. For. Ecol. Manag. 2006, 237, 267-279. [CrossRef]

85. Merganicova, K.; Merganic, J.; Lehtonen, A.; Vacchiano, G.; Sever, M.Z.O.; Augustynczik, A.L.D.; Grote, R.; Kyselova, I.; Makela, A.; Yousefpour, R.; et al. Forest carbon allocation modelling under climate change. Tree Physiol. 2019, 39, 1937-1960. [CrossRef] [PubMed]

86. Van Noordwijk, M.; van de Geijn, S.C. Root, shoot and soil parameters required for process-oriented models of crop growth limited by water or nutrients. Plant Soil 1996, 183, 1-25. [CrossRef]

87. Mokany, K.; Raison, R.J.; Prokushkin, A.S. Critical analysis of root: Shoot ratios in terrestrial biomes. Glob. Change Biol. 2006, 12, 84-96. [CrossRef]

88. Friedlingstein, P.; Joel, G.; Field, C.B.; Fung, I.Y. Toward an allocation scheme for global terrestrial carbon models. Glob. Change Biol. 1999, 5, 755-770. [CrossRef]

89. Jochheim, H.; Puhlmann, M.; Beese, F.; Berthold, D.; Einert, P.; Kallweit, R.; Konopatzky, A.; Meesenburg, H.; Meiwes, K.J.; Raspe, S.; et al. Modelling the carbon budget of intensive forest monitoring sites in Germany using the simulation model BIOME-BGC. Iforest 2009, 2, 7-10. [CrossRef]

90. Viskari, T.; Laine, M.; Kulmala, L.; Makela, J.; Fer, I.; Liski, J. Improving Yasso15 soil carbon model estimates with ensemble adjustment Kalman filter state data assimilation. Geosci. Model Dev. 2020, 13, 5959-5971. [CrossRef] 
91. Post, J.; Hattermann, F.F.; Krysanova, V.; Suckow, F. Parameter and input data uncertainty estimation for the assessment of long-term soil organic carbon dynamics. Environ. Model. Softw. 2008, 23, 125-138. [CrossRef]

92. Fodor, N.; Pasztor, L.; Szabo, B.; Laborczi, A.; Pokovai, K.; Hidy, D.; Hollos, R.; Kristof, E.; Kis, A.; Dobor, L.; et al. Input database related uncertainty of Biome-BGCMuSo agro-environmental model outputs. Int. J. Digit. Earth 2021, 1-20. [CrossRef]

93. Mao, Z.; Derrien, D.; Didion, M.; Liski, J.; Eglin, T.; Nicolas, M.; Jonard, M.; Saint-Andre, L. Modeling soil organic carbon dynamics in temperate forests with Yasso07. Biogeosciences 2019, 16, 1955-1973. [CrossRef]

94. Smallman, T.L.; Milodowski, D.T.; Neto, E.S.; Koren, G.; Ometto, J.; Williams, M. Parameter uncertainty dominates C cycle forecast errors over most of Brazil for the 21st Century. Earth Syst. Dyn. Discuss. 2021, 1-52. [CrossRef]

95. Jung, M.; Vetter, M.; Herold, M.; Churkina, G.; Reichstein, M.; Zaehle, S.; Ciais, P.; Viovy, N.; Bondeau, A.; Chen, Y.; et al. Uncertainties of modeling gross primary productivity over Europe: A systematic study on the effects of using different drivers and terrestrial biosphere models. Glob. Biogeochem. Cycles 2007, 21, GB4021. [CrossRef]

96. Soudzilovskaia, N.A.; van Bodegom, P.M.; Terrer, C.; van't Zelfde, M.; McCallum, I.; McCormack, M.L.; Fisher, J.B.; Brundrett, M.C.; de Sa, N.C.; Tedersoo, L. Global mycorrhizal plant distribution linked to terrestrial carbon stocks. Nat. Commun. 2019, 10, 1-10. [CrossRef] [PubMed]

97. Hararuk, O.; Smith, M.J.; Luo, Y.Q. Microbial models with data-driven parameters predict stronger soil carbon responses to climate change. Glob. Change Biol. 2015, 21, 2439-2453. [CrossRef] [PubMed]

98. Filser, J.; Faber, J.H.; Tiunov, A.V.; Brussaard, L.; Frouz, J.; De Deyn, G.; Uvarov, A.V.; Berg, M.P.; Lavelle, P.; Loreau, M.; et al. Soil fauna: Key to new carbon models. Soil 2016, 2, 565-582. [CrossRef] 